\title{
Annexins as Overlooked Regulators of Membrane Trafficking in Plant Cells
}

\author{
Dorota Konopka-Postupolska ${ }^{1, *}$ and Greg Clark ${ }^{2}$ \\ 1 Plant Biochemistry Department, Institute of Biochemistry and Biophysics, Polish Academy of Sciences, \\ Warsaw 02-106, Poland \\ 2 Molecular, Cell, and Developmental Biology, University of Texas, Austin, TX 78712, USA; \\ gbclark@utexas.edu \\ * Correspondence: konopka@ibb.waw.pl; Tel.: +48-22-592-5716; Fax: +48-22-658-4804
}

Academic Editors: Gian-Pietro Di Sansebastiano and Antonio Gaballo Received: 31 December 2016; Accepted: 6 April 2017; Published: 19 April 2017

\begin{abstract}
Annexins are an evolutionary conserved superfamily of proteins able to bind membrane phospholipids in a calcium-dependent manner. Their physiological roles are still being intensively examined and it seems that, despite their general structural similarity, individual proteins are specialized toward specific functions. However, due to their general ability to coordinate membranes in a calcium-sensitive fashion they are thought to participate in membrane flow. In this review, we present a summary of the current understanding of cellular transport in plant cells and consider the possible roles of annexins in different stages of vesicular transport.
\end{abstract}

Keywords: annexin; vesicular transport; membrane trafficking; stress response; Rab protein; SNARE

\section{Introduction}

Annexins are a multigene, evolutionarily conserved family of calcium- and phospholipid-binding proteins with a highly conserved tertiary structure among subfamilies from different kingdoms [1]. They are present in almost all eukaryotes, and prototypical proteins of this family are found in some prokaryotes [2-5]. The genomes of all plant and vertebrate species encode several annexins and the expression levels of certain annexins can be very high [3]. Annexins were first purified as minor contaminants of calmodulin purifications and were considered to be novel targets for $\mathrm{Ca}^{2+}$ signaling in animal cells. The contribution of annexins to plant cell adaptation to adverse environmental conditions is well documented [3,6-10]. Analyses confirmed that annexin 1 (ANNAT1) from Arabidopsis thaliana (Arabidopsis) and its homologs from different species (i.e., ANNBJ1 from Brassica juncea, NNANN1 from Nelumbo nucifera, GHANN1 from cotton, Gossypium hirutum and STANN1 from potato, Solanum tuberosum) play a role in stress tolerance of tobacco, cotton, and Arabidopsis [3,10]. In transgenic plants expressing higher levels of this annexin, degradation of photosynthetic pigments and reduction of photosynthetic activity were slower and less pronounced than in wild-type plants, and their productivity in response to different stresses was better. In some cases, ectopic expression of this annexin resulted in multi-stress tolerance [10-12]. Additionally, certain annexins are also able to alleviate oxidative stress in prokaryotic (bacterial) and animal cells, which strongly suggests that annexins can function via a very basic mechanisms, common across kingdoms [1]. So far, the precise molecular mechanism(s) of these biological phenomena is unknown. 
Annexins are also believed to be involved in membrane-related processes, such as intracellular vesicular trafficking, endo- and exocytosis, phagocytosis and autophagy, due to their inherent ability to bind and position the membrane structures in relation to each other in a calcium-dependent manner $[3,13]$. The growing body of data indicates that cellular trafficking plays an essential role in plant stress responses and adaptation to changes in the environment. In Arabidopsis, undisturbed vesicle trafficking is necessary for proper signal transmission during growth and development [14], maintenance of ion homeostasis [15,16], and tolerance to salt stress [17], water scarcity [18] or in defense responses $[19,20]$. It was shown that osmotic stress tolerance relies on both transcriptional and non-transcriptional responses. The latter implicates regulation of stomata movements [21] and membrane permeability [22] by coordination of endo-/exocytosis of plasma membrane ion channels or trafficking of water channels, respectively. Similarly, the non-transcriptional responses of stress-related phytohormones, such as abscisic acid or methyl jasmonate are, at least partially, exerted through the changes in the polar distribution of auxin transporters from the PIN family [23]. Abscisic acid is a key regulator of abiotic stress resistance and promotes endocytosis [24] as well as sequesters auxin transporters in endosomal recycling compartments [25], whereas methyl jasmonate (MeJA) effects on PIN2 subcellular distribution varies in a concentration-dependent manner, and at higher-inhibits, while at lower-induces endocytosis [26]. Auxin used to be considered to solely function in developmental processes but recent transcriptome analysis revealed a partial overlap of expression profiles between auxin-responsive genes and stress-response genes, which suggests that auxins are also involved in stress/defense responses [27].

We speculate that plant annexins are among possible $\mathrm{Ca}^{2+}$ effectors that control intracellular membrane flow either by direct interaction with membrane structures or indirectly, e.g., by rearrangement of actin cytoskeleton [28]. In this context, the strongest evidence supporting this hypothesis came from the early work on mammalian annexins [29]. In this study, annexins A1, A4, A5, A6, A7 (ANXA1, ANXA4, ANXA5, ANXA6 and ANXA7, respectively) were expressed in wild-type and 13 secretory yeast mutants (secs) [30]. The latter included the ten sec mutants impaired in the late secretory pathway (LSC; sec1, $\sec 2, \sec 3, \sec 4, \sec 5, \sec 6, \sec 8, \sec 9, \sec 10$ and $\sec 15)$, two mutants defective in the transport from endoplasmic reticulum (ER) to the Golgi complex (Golgi) transport (sec17 and sec18), and one mutant with pleiotropic defects (sec14). Yeasts lack endogenous annexins so observed effects were due to non-specific interactions between annexins and secretion machinery, and not due to complementation. None of the annexins provided full complementation of any of the sec mutants, but specific interactions were observed for ANXA1, ANXA6 and ANXA7 with the sec 2 mutant, and between ANXA7 and $\sec 4$ and sec15. Whereas annexin A7 inhibited the growth of sec 2 , sec 4 and $\sec 15$ mutants defective in exocytosis, ANXA1 and ANXA6 reduced the lag time associated with adaptation of sec 2 mutants to galactose-containing medium. The latter could be due to annexin-mediated correction of the defective insertion of the galactose permease into the plasma membrane (PM). Summarizing, certain annexins were able to influence specific steps in membrane trafficking associated with yeast cell growth, secretion and the plasma membrane (PM) remodeling.

The purpose of this review is to highlight the recent advances in plant membrane trafficking and consider the recent data suggesting roles for annexins in membrane trafficking. New insights into our understanding of the complex network of membrane trafficking in plant cells as well as new findings on plant annexin function are discussed.

\section{Annexin Characteristics}

Although the primary amino acid sequences of annexins differ significantly the overall structure of proteins from this superfamily is well preserved with four well recognizable repeats (I-IV) of approximately 70 amino acids (PFAM (database of curated protein families) domain PF00191, 66 aa). 
Each of these repeats has the potential to have a type II $\mathrm{Ca}^{2+}$-binding bipartite motif, located on two different $\alpha$-helices (GxGT-(38-40 residues)-D/E), but typically some of them are non-functional. In plant annexins the $\mathrm{Ca}^{2+}$-binding motif is highly conserved in repeat I, generally lost in repeats II and III, and only moderately conserved in repeat IV [3,13]. For example, Arabidopsis ANNAT1 and ANNAT2 have conserved $\mathrm{Ca}^{2+}$-binding motifs in repeats I and IV but not in repeats II and III, while ANNAT4 is more divergent (Figure 1A). In contrast, in vertebrate annexins three repeats (I, II and IV) are well preserved [1,3,13]). Each single annexin domain is comprised of $5 \alpha$-helices (A-E). Four of them (A, B, D and E) are arranged parallel and form a tightly packed helix-loop-helix bundle. In contrast, helix $C$ is almost perpendicular and covers the remaining four on the surface [13]. The core of the helix bundle is composed largely of hydrophobic residues, while hydrophilic residues are exposed on the surface of the protein and between the domains. The tertiary structure of annexins is evolutionary conserved; a single molecule resembles a slightly curved disk with the calcium and phospholipid-binding sites located on the more convex surface and the more concave surface facing the cytoplasm. Despite the significant structural similarities responsible for their central property of $\mathrm{Ca}^{2+}$-dependent lipid binding, individual eukaryotic annexins are considerable specific; for example, they differ significantly in their calcium binding affinity and hence also in their membrane binding. In smooth muscle cells, annexins act as an intracellular $\mathrm{Ca}^{2+}$ sensors and were shown to translocate to the PM sequentially, according to their decreasing calcium affinity [31,32]. A mechanism of membrane binding was proposed which assumes that calcium ions are coordinated jointly by $\mathrm{Ca}^{2+}$-binding site and membrane phospholipids (membrane bridging mechanism) [33]. Accordingly, the calcium binding affinity of individual annexins has to be regarded only in relation to the composition of the interacting membrane. Membrane binding results in conformational changes and the slightly curved annexin molecule is transformed into more planar disc [34]. Such modification can reveal the secondary phospholipids binding sites on the concave surface and allows for the apposition of membrane structures [35] (Figure 1B).

Annexins are classified according to the evolutionary divisions of the eukaryotes into five families: A (ANXA, vertebrates, including humans), B (ANXB, invertebrates), C (ANXC, fungi), D (ANXD, true plants), E (ANXE, protists) [36]. The best characterized is the monophyletic A family, where 12 distinct subfamilies are encoded by 12 paralogous genes (ANXA1-ANXA11 and ANXA13). The second, truly monophyletic clade is Archaeplastida that consist of green and red algae, and contemporary green land plants [2]. In contrast, neither fungi nor protists are regarded as a monophyletic clade and different groups within can possess and lack these proteins [2].

The possible role of annexins in membrane trafficking and secretion was originally suggested due to their ability to "annex" membranes and potentially aid in secretory vesicle fusion with the PM (Figure 1B) $[3,13]$. Annexins not only bind to abundant phospholipids in membranes such as phosphatidylserine but also interact with the more minor membrane phospholipids such as negatively charged phosphatidylinositols, phosphatidylglycerol and phosphatidic acid. The paradigm for annexin function is based on their $\mathrm{Ca}^{2+}$-dependent membrane-binding property that allows them to move from the cytosol to membranes when cytosolic $\mathrm{Ca}^{2+}$ levels increase in response to a stimulus. Thus annexins are viewed as dynamic, signaling proteins providing important links between intracellular $\mathrm{Ca}^{2+}$ signals and the regulation of various membrane functions, such as lateral membrane organization, cytoskeleton interaction with cellular membranes and membrane flow. 
A.
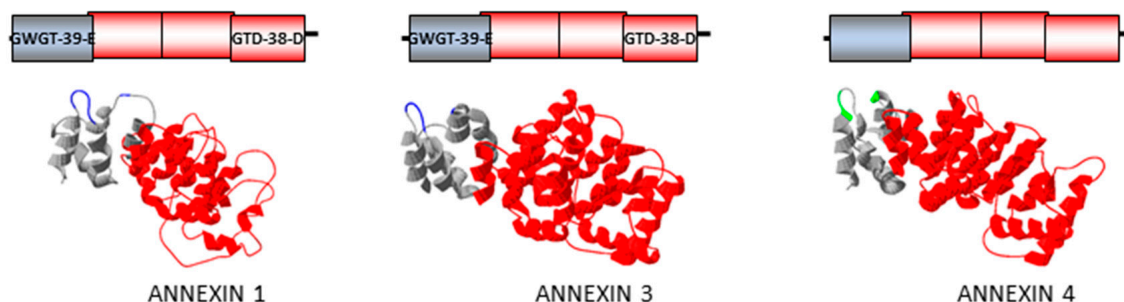

GWGT-39-E Endonexin domain I

Endonexin domains without conserved

Endonexin domain

GTD-38-D Endonexin domain IV with conserved $\mathrm{Ca}^{2+}$ - and phospholipid-binding motif

B.

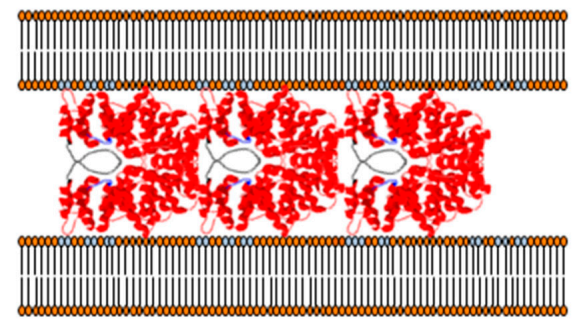

Figure 1. Predicted structure of three Arabidopsis annexins and proposed mechanism for annexinmembrane coordination. (A) Predicted structure of three Arabidopsis annexins, ANNAT1, ANNAT3, and ANNAT4. The structure was prepared with Swiss-PdbViewer, DeepView v4.1 by Nicolas Guex, Alexandre Diemand, Manuel C. Peitsch, and Torsten Schwede on the basis of existing annexin crystal structures. The overall structure of annexins is evolutionary conserved. The molecule consists of four repeats (I-IV) of approximately 70 amino acids (PFAM domain PF00191, 66 aa). In plant annexins the type II Ca ${ }^{2+}$ - and phospholipids binding motif (GxGT-(38-40 residues)-D/E) is highly conserved in repeat I (in grey), generally lost in repeats II and III, and only moderately conserved in repeat IV (in red). In Arabidopsis, the canonical motif is present in repeat 1 of annexin 1 and 3 and a modified motif in repat IV of annexin 1 and 3. In annexin 4 there is no recognizable calcium and phospholipids binding motifs; (B) Possible mechanism of membrane coordination by annexins, according to [34,37]. Two opposing membranes can be coordinated by dimerizing annexin molecules. Binding to the membrane causes changes in molecular conformation and flattening of protein disc. As a result, a secondary calcium- and membrane-binding sites on the concave surface disclose, which allows positioning of the various membrane structures.

\section{Membrane Flow in Eukaryotic Cells}

Eukaryotic cells are subdivided by an endomembrane system into a series of discrete compartments. The diversification of the internal cellular environment enables different functions to be carried out simultaneously, such as synthesis sorting and degradation of macromolecules (proteins, lipids and cell wall precursors), and secondary metabolism. The morphology, functions, lipid and protein compositions of individual organelles are specifically designed to support individual functions. Though cellular compartments are not continuous they stay interconnected through vesicle transport systems and proteins. Lipids are constantly exchanged between different structures. In addition, membrane transport systems allow cells to stay in contact and exchange information with their environment by supporting uptake (endocytosis) and export (exocytosis) of macromolecules, particles and other chemical compounds. 
In plant cells, the main organelles of the endomembrane system are the ER [38], the Golgi, comprised of numerous dispersed Golgi stacks called dictyosomes [39] and the trans-Golgi network (TGN) [40], multivesicular bodies/prevacuolar compartment (MVB/PVC) [41], lytic and protein storage vacuoles (LV and PSV, respectively) [42,43], the PM and the endocytic compartment [44,45]. Based on rapid labeling with the fluorescent endocytic tracer FM4-64 and morphological similarities it is generally accepted that in plants the TGN functions like the early endosome compartment (EE) in animal cells $[41,46,47]$. The next structure labeled by FM4-64 is the MVB/PVC which suggests that it is the plant equivalent of the late endosome compartment (LE) in animal cells. In plant cells, acidic vacuoles then function as lysosomes.

Membrane compartments communicate constantly with each other by means of transport vesicles. As in all other eukaryotes, there are two main pathways of membrane flow in plant cells: secretory and endocytic pathways $[48,49]$. Within the early secretion pathway (ESP), which includes the ER and the Golgi [47], vesicle trafficking occurs in two opposite directions. In forward (anterograde) trafficking, all newly synthesized proteins intended for secretion are exported from the site of their synthesis in the ER to the default destinations. In the Golgi, cargo and membrane molecules are sorted between $\mathrm{PM}$ /apoplast and tonoplast/vacuole lumen that collectively form the late secretion pathway (LSP) [47].

At each step of their transport, proteins can be turned back from their forward route by reverse (retrograde) trafficking. Transport within the ESP is mediated by coat protein complex II (COPII)-coated vesicles that bud off from the ER membranes and COPI-coated vesicles that are released from Golgi cisternae [50,51]. COPII-coated vesicles are involved in anterograde ER-to-Golgi transport, whereas two types of COPI-coated vesicles mediate retrograde traffic from Golgi-to-ER (COPIa) and transport between the Golgi cisternae (COPIb) [50]. A third type of vesicle, clathrin-coated vesicles (CCV), operates within the LSP and supports both forward transport and delivery of endocytosed material to the endosomes. The second distinct secretion route supports delivery of the precursors of cell wall polysaccharides synthesized in the Golgi $[52,53]$. Cellulose is the only component of the cell wall that is produced in situ at the cell surface by the PM localized enzymes, whereas hemicelluloses and pectin precursors are synthesized in the Golgi and only then are transported to the cell surface and assembled into polymers [54-56]. It is estimated that up to $80 \%$ of the metabolic activity of the Golgi in plant cells is engaged in polysaccharide synthesis. In the ESP, retrograde traffic counterbalances the continuous forward flux, and enables the cell to maintain the size of the different compartments as well as to recycle components of the resident transport machinery to the appropriate compartment and prevent loss of resident proteins captured by coincidence from donor compartment [57].

Much less is known about the LSP. The TGN is the first site where the biosynthetic/secretory and endocytic pathways intersect [49]. At the TGN, secretory trafficking could potentially branch out toward the different post-Golgi compartments, i.e., PM or PVCs/MVBs $[40,57,58]$. Proteins with no sorting signal/signals are transported to the PM as a default. Other proteins carrying vacuole sorting signal/signals (VSSs) are recognized by the appropriate vacuolar sorting receptor and transported into PVCs though there are also some indications that recognition of cargo by VSRs may occur already in the ER [59-62]. Receptors and membranes are returned to the TGN for the next cycles of delivery. Trafficking within the LSP is mediated mainly by clathrin-coated vesicles (CCVs). These vesicles are formed at the PM during endocytosis and at the surface of the trans-Golgi network, and they support receptor-mediated post-Golgi trafficking as well as endocytic protein transport.

Trafficking of soluble cargo to the vacuoles occurs not only by the TGN but also via other routes that have recently been described. There is evidence showing that vacuolar proteins can bypass the Golgi (non-conventional secretion pathways) [63], or first reach the PM and only then come back to the vacuole, because undisturbed endocytosis is required for proper development of vacuolar system [64]. Additionally, an intermediate compartment between the PVC and the LV was described in the leaf epidermis of tobacco (Nicotiana tabacum) [65], where proteins can be stored for various lengths of time before reaching their final destination. Moreover, additional non-Golgi secretion pathways of 
leaderless proteins are still being discovered [66]. A schematic depiction of membrane trafficking in plant cells is shown in Figure 2.

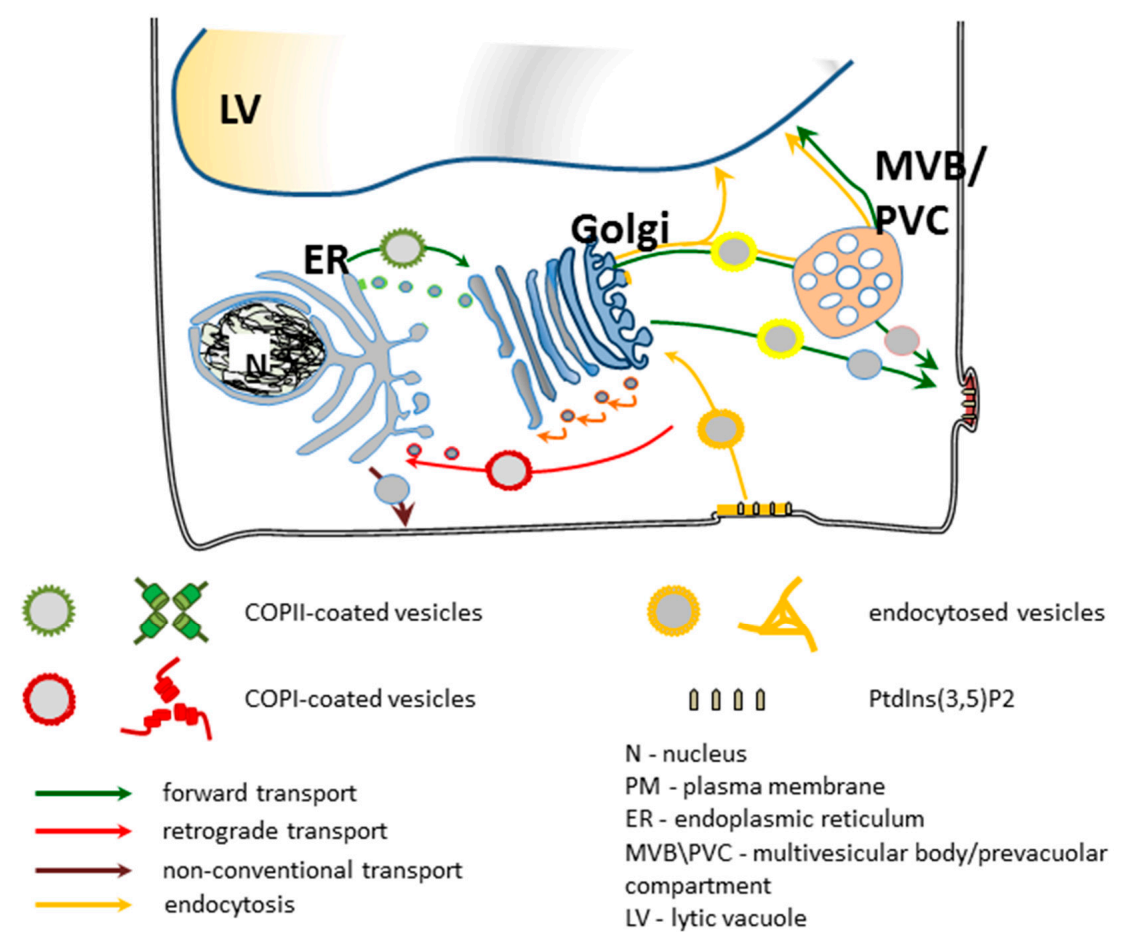

Figure 2. Model depicting intracellular transport in plant cells.

In silico analysis predicts that more than $17 \%$ of all Arabidopsis proteins enter the endomembrane system to be transported via the Golgi to the different default designations [67]. Proteins having $\mathrm{N}$-terminal leader sequences are co-translationally inserted into ER lumen through the SEC61 pore complex [68] where they subsequently undergo $N$-glycosylatation. This modification recruits enzymes required for the proper folding of a nascent polypeptide and the machinery responsible for quality control [69]. Properly folded proteins are either retained within the ER or concentrated at discrete domains of the ER exit sites (ERES) specialized for secretion and then incorporated into nascent COPII-coated vesicles for delivery to the Golgi [70]. In the Golgi, proteins undergo final maturation and are sorted to the vesicles traveling to the appropriate default localization (apoplast/PM or tonoplast/vacuole) based on the presence of the short amino acid signaling sequences (sorting motifs). Transport between the ER and the Golgi requires energy and small monomeric GTPases from the ARF family. The very last Golgi cisterna in the TGN is also a site where forward and retrograde protein flows meet. It functions as a sorting station at the crossroads of the endo- and exocytic pathways. Endocytic retrograde route enables both retrieval of trafficking machinery and degradation of already dispensable membrane proteins. Correct targeting of vesicles relies on the presence of specific tags on the donor compartment and fitting tags on the vesicles. Fusion of Golgi-derived vesicles carrying newly synthesized vacuolar proteins and from early/recycling endosomal compartments generates multivesicular body (prevacuolar compartment, MVB/PVP). Within MVB/PVC, two kinds of sorting processes occur-the recycling of vacuolar cargo receptors mediated by the retromer complex and the sorting of PM protein into internal vesicles by the ESCRT machinery.

Undisturbed membrane trafficking is of key importance for maintaining homeostasis and stress responses in all eukaryotic organisms. Mutations in membrane trafficking proteins that block secretion are often lethal. While not lethal, many annexin loss-of-function mutants are sensitive to stress and their corresponding gain-of-function mutants are stress tolerant. These phenotypes may be due to their antioxidant activity, $\mathrm{Ca}^{2+}$ transport activity and and/or their role in regulating membrane 
trafficking. In yeast (Saccharomyces cerevisae) mutants without a vacuole are viable despite severe biogenesis defects [71,72]. In contrast, in plants, vacuoles are essential for development and annexins can associate with the vacuolar membrane at physiologically relevant $\mathrm{Ca}^{2+}$ levels. Usually mutations that disrupt their development and/or morphology, such as the Arabidopsis vacuoleless (vcl)/vps16, are embryo lethal [71,73]. As well, mutations that disrupt single syntaxin genes (protein that form a SNARE complex executing membrane fusion) are frequently lethal at the phase of gametophyte or seedlings development [14,74-77].

\section{The Role of Calcium in Plant Membrane Trafficking}

The role of $\mathrm{Ca}^{2+}$ in intracellular membrane trafficking is still poorly characterized. For a long time it has been known that in animal cells transient elevations of $\mathrm{Ca}^{2+}$ ions in the cytosol triggers the fusion of secretory granules and synaptic vesicles with the PM. But in fact, membrane fusion occurs many times during the secretory pathway, not only at the $\mathrm{PM}$, so $\mathrm{Ca}^{2+}$ could potentially affect all these steps.

The best recognized model of the $\mathrm{Ca}^{2+}$-regulated membrane trafficking event is neuronal SNARE-mediated exocytosis that supports quantal release of neurotransmitters. As such, SNAREs are not $\mathrm{Ca}^{2+}$ sensitive proteins and assembling of trans-SNARE complexes at the interface between synaptic vesicle and plasma membrane as well as subsequent fusion of bilayers are basically not calcium-dependent processes. Calcium responsiveness is conferred by an additional interactions with $\mathrm{Ca}^{2+}$-binding proteins, such as synaptotagmins or calmodulins [78-80] that are activated in different but overlapping ranges of $\left[\mathrm{Ca}^{2+}\right]$. Synaptotagmins ensure the synchronization of $\mathrm{Ca}^{2+}$-dependent exocytosis with the presynaptic action potential [78]. The effect of calmodulins is much more complex, as they interact with multiple target proteins implicated in exocytosis, e.g., individual Soluble NSF Attachment Protein Receptor (SNAREs; e.g., VAMP2, AtSYP13 [79,81], $\mathrm{Ca}^{2+}$ channels, $\mathrm{Ca}^{2+} /$ calmodulin kinase II [82-84], Rab3A [82,84,85] and Munc13 [85,86]). While doing so, calmodulin and synaptotagmin can cooperate to define the range of concentrations, in which exocytosis occur.

With the accumulation of more data it has become clear that $\mathrm{Ca}^{2+}$ is a basic cofactor required for fusion of different biological membranes [87-93]. The constitutive secretory pathway seems to be a mosaic of $\mathrm{Ca}^{2+}$-dependent and $\mathrm{Ca}^{2+}$-independent processes. Addition of membrane-permeant chelators to intact, living cells results in inhibition of both anterograde and retrograde transport, but subsequent transport steps were affected to different extents [94]. The initial step of the secretory pathway, i.e., COPII vesicle fusion, was not inhibited by $\mathrm{Ca}^{2+}$ chelators, while the second step, trafficking between the ER and Golgi intermediate compartment (ERGIC) and within the Golgi was inhibited. Downstream of the Golgi, there were no retention points between the PM. As well, endocytosis was not impaired, while endosome-to-Golgi and Golgi-to-ER trafficking were blocked [89].

Collectively, the data described above strongly suggests that one of the possible mechanism of calcium action is modulation of activity of transport-related proteins, such as annexins, small GTPases of RAB family or vesicle coat proteins. Besides Rab3A in neurons the activity of Rab11a in contractile vacuoles of Dictyostelium discoideum was shown to be controlled by the targeted $\mathrm{Ca}^{2+}$ release through an ion channel P2XA [95]. In pneumocytes, $\mathrm{Ca}^{2+}$ entry via vesicular P2X4 channels was reported to promote the opening of fusion pores and release of the vesicle content [96]. Thus, the calciumdependent regulation of Rab proteins may be a common phenomenon, but the range of this mechanism remains an open question. P2X receptors are also expressed on intracellular membranes in some cell types of multicellular organisms, though they are not found in higher plants [97]. However, treatment of plants with extracellular ATP (eATP) induces $\mathrm{Ca}^{2+}$ influx in plants [98-102] and eATP regulates growth in a variety of plant cells and tissue [103]. Recently a lectin kinase receptor was identified as the first plant eATP receptor [104]. Interestingly, eATP-mediated $\mathrm{Ca}^{2+}$ release in response to salt treatment was impaired in an Arabidopsis annexin mutant [105].

Calcium was also found to stabilize of COPI/COPII vesicle coat. ALG-2 (apoptosis-linked gene 2) is a $\mathrm{Ca}^{2+}$-binding protein that acts as a $\mathrm{Ca}^{2+}$ sensor on the membrane of ER export sites where COPII coated vesicles form and the presence of $\mathrm{Ca}^{2+}$ the association of the sec31 subunit with the membrane 
is stabilized [106]. The $\mathrm{Ca}^{2+}$ sensor for COPI retention on the Golgi has not been identified yet but the yeast equivalent of the COPI coat tethering at the Golgi membranes requires, among other proteins, the Rab GTPase, ScYPT1 and the USO1 protein [107]. The latter is homologue of golgin p115 [108], which tethers Rab1 to COPI vesicles to the cis-Golgi. A single point mutation in ScYPT1 (YPT1 ${ }^{1 \mathrm{le} 121}$ ) results in temperature-dependent dominant-lethal phenotype in mutant cells. A mutation in SLY1 results in the elevation of $\mathrm{Ca}^{2+}$ levels in the cytosol and suppresses this phenotype [109,110]. $\mathrm{Ca}^{2+}$ does not substitute for the specific USO1- or YPR1-dependent tethering process, instead, it bypasses the need for efficient vesicle tethering.

A second possible mechanism of $\mathrm{Ca}^{2+}$ action on membrane fusion can be attributed to the physical interaction of the ions with acidic phospholipids such as phosphatidylinositol phosphates resulting in modification of the physical properties of bilayer. In model membrane fusion systems calcium ions increased the rates of lipid mixing and promoted the formation of fusion pores [111]. Interaction can also reduce the energy barrier of membrane clustering to produce hemifusion state (fusion of only external leaflets of two lipid bilayers) and then stabilize highly curved membrane. Depending on lipid composition and $\left[\mathrm{Ca}^{2+}\right]_{c y t}$, their interaction can promote negative or positive membrane curvature, which in turn influences fusogenicity of many biological membranes [112].

Finally, the $\mathrm{Ca}^{2+}$-mediated regulation of membrane fusion events can have an indirect effect, such as stabilizing of COPI and COPII coats [113] or inducing re-arrangement of actin microfilaments [114-117]. Proper coat assembly is required to form the vesicles themselves and to select cargo as well as for biogenesis of the ESP compartments $[89,118,119]$. Actin microfilaments create tracks for secretory vesicle movement and actin polymerization-driven processes may control vesicle budding and movement of endosomes, so $\mathrm{Ca}^{2+}$ can also regulate endocytosis [120]. In animal cells, fusion of endosomes and lysosomes is controlled by transient increases in cytosolic $\mathrm{Ca}^{2+}$ ions and the action of two downstream effectors, calmodulins [88,90] and Rab GAP proteins [95].

Less is known concerning such processes in plant cells but the high level of evolutionary conservation of overall tertiary structure strongly supports the likelihood that annexins may also function as $\mathrm{Ca}^{2+}$ effectors regulating intracellular membrane flow in plants. Additionally, direct measurements of vesicle fusion using patch clamp techniques in a single aleurone protoplast revealed that exocytosis in plants is also a $\mathrm{Ca}^{2+}$-dependent process [111]. Secretion of individual proteins was also shown to be a $\mathrm{Ca}^{2+}$-dependent process (e.g., inducible secretion of peroxidases in order to loosen cell wall to enable cell elongation) [121]. Finally, a $\mathrm{Ca}^{2+}$ gradient in polarized cells contributes to the control of secretion of cell wall material [122].

However, some differences in how plant annexins regulate membrane flow, resulting from different cytoarchitecture and physiology, should be expected. In plant cells the ER is a not a major intracellular $\mathrm{Ca}^{2+}$ store as it is in animal cells. Because the large central vacuole and apoplast in plants also participate in $\mathrm{Ca}^{2+}$ storage [123], $\mathrm{Ca}^{2+}$ signaling is spatially different in plant cells [87]. Plant secretion pathways also have several unique features distinguishing it from comparable routes in animal cells, so in the following section we will summarize the status of current knowledge about plant membrane trafficking.

\section{Annexins in Membrane Trafficking}

\subsection{What Is Known from Vertebrate Annexins}

Since their discovery in animal cells, one of the earliest and most often suggested function for this protein family has been a participation in the process of secretion. To the extent that the function of annexin in plants might parallel its function in animals, it is worth considering the reports of animal annexin participation in membrane trafficking and endocytosis. In the early studies the best evidence for a role in secretion was for ANXA7, originally known as synexin. It was postulated to participate in secretion due to its membrane fusion properties promoted by $\mathrm{Ca}^{2+}$ and GTP $[124,125]$. It promoted very vigorous aggregation of yeast secretory vesicles in vitro, in contrast to ANXA2, 
which was only weakly active in the yeast vesicle aggregation assay [29]. Another annexin, ANXA13b, was found to function in apical secretion by association with lipid microdomains [126]. Besides the PM in BHK cells there are also all other membrane compartments, such as nuclear envelope, the ER, the Golgi, the plasma membrane, early endosomes (EE), late endosomes (LE) and lysosomes was clearly identified as a target for annexins binding [127]. Later on, there is also a role for annexins in the endocytic pathway [128] including intracellular positioning of recycling endosomes [129] and the biogenesis of multivesicular body (MVB) $[130,131]$. ANXA2 was also shown to be required for establishing cell polarity, cytokinesis and endocytosis in HeLa cells [].

Beyond these original studies, evidence that certain animal annexins function in different stages of membrane trafficking has continued to be obtained. Over a dozen annexins can be expressed in a single mammalian cell forming a sophisticated $\mathrm{Ca}^{2+}$-sensing network and are able to bind to membranes in a concentration-dependent manner, beginning from the most sensitive ANXA2 followed subsequently by ANXA6, ANXA4 and ANXA1 [132,133]. Moreover, after induction they are translocated to distinct membranes [31,32]. ANXA1 and ANXA2 were translocated to the endosomal membrane, with ANXA2 additionally being involved in intracellular vesicle movements. ANXA5 was associated with the LE and the Golgi, ANXA6 with the Golgi, vacuolar membranes and the ER. ANXA1 and ANXA5 localized to the nucleus. These results suggest that particular annexin is functionally specialized to control individual set of subcellular membranes in response in diversified manner. $\mathrm{Ca}^{2+}$ is known to regulate different aspects of secretion and vesicle trafficking, beginning at the very initial stages-transport from the ER to the Golgi up to the fusion with the PM and endocytosis. However, the role of $\mathrm{Ca}^{2+}$ in the early stages of secretion is still poorly understood, especially relative to the rather extensive knowledge about its function in the different phases of the LSP beyond the Golgi, such as vacuolar transport, exocytosis, endocytosis, recycling of membrane components. There is now evidence that $\mathrm{Ca}^{2+}$ helps to regulate secretion and vesicle trafficking at the different stages of vesicular trafficking by means of the interaction with annexins. Within the ESP, ANXA11 was shown to regulate the ER-to-Golgi transport by stabilizing the SEC31A protein (a component of an outer cage of COPII-coated vesicles) at the ER [113]. ANXA2 is found at exocytotic sites in chromaffin granules and is needed for $\mathrm{Ca}^{2+}$-dependent formation of lipid microdomains essential for exocytosis in these cells [134]. Decreased expression of ANXA2 results in inhibited exocytosis in chromaffin granules. More recently, another study found that binding of ANXA2 to membranes induces formation of microdomains enriched in cholesterol and phosphatidylinositol 4,5-bisphosphate [PtdIns $\left.(4,5) \mathrm{P}_{2}\right]$ and also inward vesicle budding in giant unilamellar vesicles [135]. Finally, it was shown that the ANXA2 was able to partially restore $\mathrm{Ca}^{2+}$-dependent secretion in digitonin permeabilized chromaffin cells [136]. A key role in the events leading to exocytosis was assigned to a 16 amino acid peptide (P16), corresponding to C-terminal end of ANXA2 (shared with 14-3-3 proteins). The partial effect of $\mathrm{P} 16$ on secretion under a variety of experimental conditions suggests that the annexin is not essential for exocytosis but only regulate its extent possibly by establishing in a calcium-dependent manner protein-protein interactions [137]. There is both in vitro and in vivo evidence that ANXA7 regulates catecholamine release from stimulated chromaffin cells and the BoNT type C-mediated inhibition of membrane fusion relies on the cleavage of ANXA7 [138]. Animal annexins were also recently found to be involved in endocytic trafficking [139]. ANXA2 facilitates endocytic trafficking of antisense oligonucleotides used as tools in this research [140]. Recent studies also revealed involvement of the ANXA1 in membrane trafficking events [141,142]. ANXA1 and ANXA2 were shown to participate in retrograde trafficking $[143,144]$ and annexin A2 was proposed to play a role in the biogenesis of MVBs [131]. A similar study showed that ANXA1 was required for EGF-stimulated inward vesiculation in multivesicular endosomes [145]. Two mechanisms of endosomes fusion was proposed, one that relay on calcium and annexins, and another that is calcium independent [146].

Finally, abundant studies suggest that annexins are important for membrane repair. This process is induced by uncontrolled influx of extracellular $\mathrm{Ca}^{2+}$ and requires intact membrane trafficking [147]. Depending of the type of membrane injury different mechanisms of membrane repair have been 
described, including: (i) $\mathrm{Ca}^{2+}$-activated, homotypic vesicle fusion and patch formation, which undergo exocytosis [148]; (ii) endocytosis of the membrane regions permeabilized by pore forming toxins or mechanical wounded [149,150]; (iii) blebbing, formation of the protrusions from the damaged membrane segments locally detached from cortical cytoskeleton with adjacent cytoplasm [151]. Annexins are able to induce aggregation and fusion of intracellular vesicles/lysosomes and thus can assist exocytosis and offer a scaffold for endosome formation. ANXA1 and ANXA2 contribute to membrane repair by aggregation and fusion of intracellular vesicles [152]. The blebs are sealed off from the cell body by plugs of ANXA1 [151]. ANXA5 in turn can form a two-dimensional network beneath the injured plasma membrane [153]. Finally, ANXA6 assemble a "cap" on the membrane repair patch [154].

\subsection{Plant Annexins}

All of the contemporary families of plant annexins originate from one to three founding members in mosses and ferns [3]. The main expansion of annexin genes in plants occurred at about 450 mya during colonization of the more challenging drought-prone land environment, before the divergence of monocots and dicots [155]. Thus far, more than 400 plant annexins have been identified and based on primary amino acid sequence grouped in 17 phylogenetically related subfamilies. Just as their animal counterparts plant annexins form multi-member families in a respective species (8 in Arabidopsis [156]; 9 in rice Oryza sativa [157]; 12 in maize Zea mays [158] and potato Solanum tuberosum [10]; 11 in Solanum lycopersicum [159]; and 23 in soybean [158]).

Plant annexins were first purified based on their ability to bind phospholipids/membranes in a $\mathrm{Ca}^{2+}$-dependent manner. They have been found to be associated with vacuolar, nuclear and plasma membranes as well as the Golgi and Golgi-derived vesicles [160-162]. Results suggesting annexin involvement in plant secretory processes first came from early localization studies. Using immunological approaches annexins were located at the tips of polarly growing cells such as pollen tubes and fern rhizoids $[163,164]$. Further, immunolocalization studies in peas found high levels of annexin immunostain in other highly secretory cell types, such as young, developing xylem cells and outer root cap cells [160]. In this study, immunogold localization showed annexin association with the trans-Golgi membranes, Golgi-derived secretory vesicles and PM. It is noteworthy that the level of immunogold labeling of annexin in root cap cells greatly increased as the root cap cell progressed toward the periphery transitioning into highly secretory outer root cap cells. Another early study also showed that plant annexins, like animal annexins, can induce aggregation of secretory vesicles in vitro [165].

The results from the early studies were only suggestive of a role for plant annexins in secretory processes. However, in two landmark papers, a maize annexin was demonstrated to induce aggregation of secretory vesicles [165] and to directly have a positive effect on exocytosis in root cap protoplasts [166]. The addition of annexin protein promoted $\mathrm{Ca}^{2+}$-dependent secretion of polysaccharides from root cap cells, while anti-annexin antibodies blocked this ability. Interestingly, addition of GTP inhibited secretion in the root cap protoplast cells.

The results from more recent studies have provided evidence that plant annexins play an important role in abiotic and biotic stress responses. Ectopic expression of Arabidopsis ANNAT1 and its homologs confers tolerance to drought, osmotic and salt treatments as well as tolerance to pathogen attack. These stress tolerant phenotypes observed are likely due to the antioxidant activity associated with this annexin. This protein activity persists across biological kingdoms [12,167-172]. For example, expression of ANNAT1 homologs can limit lipid peroxidation levels induced by stress treatments. The precise mechanism of action for plant annexin antioxidant activity is still unclear, however certain animal and plant annexins have conserved redox-sensitive cysteine residues, such as Cys-8 in mammalian ANXA2 [173,174]. Irreversible inhibition of this cysteine by $N$-ethylmaleimide treatment did not interfere with phospholipid binding, however it abolished in vitro liposome aggregation. Cys-8 can possibly undergo repeated redox cycles and after oxidation by ROS it can 
subsequently be reduced by the thioredoxin system [174]. Indeed, compared to the control cells ANXA2 depleted cell lines accumulated higher levels of ROS, as well as displayed increased activation of the oxidative stress-induced proapoptotic kinases (p38, JNK, AKT) and a higher level of cell death [174]. Plant annexins may utilize a similar mechanism, possibly even more so as they possess multiple reactive cysteines [6]. Interestingly, ectopic expression or overexpression of certain plant annexins also induces changes in gene expression [12]. This observation suggests the possible $\mathrm{Ca}^{2+}$-induced translocation of annexin to the nucleus [161,174-177]. However, as discussed earlier annexins could also function in stress responses by regulating endocytosis and exocytosis, which is known to play a critical role in plant stress responses.

There are also a number of biochemical properties found in plant annexins that could be important for regulating endocytosis and exocytosis processes, including F-actin binding, modulation of $\mathrm{Ca}^{2+}$ influx activity and association with lipid microdomains. Plant annexins from different species have been shown to bind F-actin in vitro [178-180], and some have an IRI motif found in their fourth repeat that is potentially responsible for actin binding. There is a review highlighting the importance of annexins in regulating actin filament organization and dynamics in plants [181].

$\mathrm{Ca}^{2+}$ is a critical signal in directing polarity in plant cells, and membrane trafficking is one important component for establishing and maintaining cell polarity [182]. While it is still controversial whether some plant annexins act directly as $\mathrm{Ca}^{2+}$-permeable channels, it is clear that certain plant annexins modulate $\mathrm{Ca}^{2+}$ influx. For example, ANNAT1 has been shown to facilitate $\mathrm{Ca}^{2+}$ influx in response to $\mathrm{H}_{2} \mathrm{O}_{2}$, which can regulate growth $[9,183]$. Certainly their presence at the tip of polar growing cells suggests a possible role in regulated $\mathrm{Ca}^{2+}$ influx during cell expansion.

Association with lipid microdomains is an important component of annexin-mediated exocytosis in animal cells. These microdomains are detergent-resistant membrane fractions, and plant annexins have recently been identified in such fractions [184]. Although these in vitro findings do not necessarily indicate that annexins function in membrane microdomains in vivo, some initial experiments on the transient expression of ANNAT1 in Nicotiana benthamiana showed that it co-localizes in situ with a lipidated fluorescent protein that is specific for sterol-enriched membrane microdomains [185].

However, in vivo, there may be exceptions to this paradigm for annexin function as certain annexins are able to bind to membranes in $\mathrm{C}^{2+}{ }^{2+}$-independent manner and some annexins are also found in the apoplast, e.g., ANNAT1 [186].

\subsection{Plant Annexins in Membrane Trafficking-Where We Are Now}

There are eight members of the annexin gene family in the model plant, Arabidopsis (ANNAT1-8). Studies on these annexins have demonstrated that different ones have both distinct and overlapping tissue- and developmentally-specific expression patterns as well as different sub-cellular localization [156]. There are also data suggesting that certain plant annexins are multifunctional. The best example of such protein is ANNAT1, the most abundant and well-studied annexin in Arabidopsis. It and its homologs in other plant species have been shown to promote $\mathrm{Ca}^{2+}$ influx as well as have antioxidant activity. It also appears to play important roles in seed germination as well as abiotic and biotic stress responses [3,7,187].

Data collected so far showed that in Arabidopsis cells individual annexins has a potential to regulate membrane events in different cellular compartments (Figure 2). ANNAT1 has been found in the PM proteome [188], while ANNAT3 was found in the tonoplast proteome [189]. Another Arabidopsis annexin, ANNAT4, was shown to interact with two sets of Qa SNAREs located at PM (AtSYP121, AtSYP122, AtSYP123) and at the PVC/tonoplast (AtSYP21 and AtSYP22) [190]. Localization studies indicate that ANNAT1 may also function in secretion. There is a strong correlation between the immunolocalization patterns for ANNAT1 and ANNAT2 and the secretion of polysaccharides, as assessed using ${ }^{3} \mathrm{H}$ galactose in young seedlings [164]. There are also clear differences between ANNAT1 and ANNAT2 in their localization patterns: ANNAT1 is located at the cell periphery of root epidermal cells, root hairs and root cap cells while ANNAT2 is located at the cell periphery of 
hypocotyl and cotyledon epidermal cells. These results suggest that ANNAT1 and ANNAT2 can regulate Golgi-mediated secretion of polysaccharide precursors to the PM.

Two other Arabidopsis annexins, ANNAT3 and ANNAT5, have also been implicated in membrane trafficking. In the case of ANNAT3, recent evidence suggests it has a direct role in post-Golgi vacuolar transport [191]. Another study utilizing RNAi found that knock-down of ANNAT5 expression in Arabidopsis pollen resulted in severe sterility [192]. In the case of ANNAT5, gain-of-function mutants expressing higher levels of this annexin were resistant to brefeldin A (BFA)-induced inhibition of pollen germination and pollen tube elongation [193]. In fact, there was a positive correlation between the level of ANNAT5 expression and its ability to block BFA effects on pollen. This finding may be related to the observation that BFA-treatment of pollen has multiple effects on membrane trafficking. It promotes Golgi-mediated secretion but inhibits endocytosis [194], disrupts endomembrane trafficking by negatively affecting the formation of a specific subset of endosomes, and indirectly blocks actin polymerization at the pollen tube apex [195].

Because ANNAT5 was also shown to bind actin, the pollen of ANNAT5 gain-of-function mutant was treated with lactrunculin B (LatB) [193], which blocks actin polymerization thus inhibiting pollen germination and pollen tube elongation. Their results indicated that higher levels of ANNAT5 were not able to overcome LatB-mediated effects on pollen. So, although ANNAT5 appears to regulate endomembrane trafficking in pollen in a $\mathrm{Ca}^{2+}$-dependent manner, the exact mechanism(s) still needs to be determined.

Cotton fiber elongation is mediated by both diffuse and polar growth. The first annexin identified in cotton was shown to associate with callose synthase and potentially regulate the activity of this enzyme [196]. More recently, two cotton-fiber annexins, GHANN2 and GHFANNX, have been shown to be important in fiber elongation. RNAi silencing of GHANN2 inhibits fiber growth as well as $\mathrm{Ca}^{2+}$ influx at the tip of expanding fibers, which could be required for $\mathrm{Ca}^{2+}$ directed maintenance of polar secretion [197]. GFP-tagged GHFANNX was located on the peripheral and cytoplasmic side of the apex of cotton fiber tip, and the authors suggested this annexin can be associated with Golgi-derived vesicles in this region [198]. GHFANNXA was found to promote $\mathrm{Ca}^{2+}$ influx and cause reorganization of actin filaments in cotton fibers, two mechanisms that could potentially affect delivery of cell wall components needed for expansion [199].

\section{Secretory Trafficking Pathway}

For decades the secretory pathway in eukaryotic cells has been an object of intense study. The current knowledge of this processes in plant cells is summarized in Figure 2. Despite intense efforts, many aspects still remain unclear. In plants transport of proteins between the ER and the Golgi does not rely on cytoskeleton but is energy dependent. Two mechanisms of ER-to-Golgi transport of newly synthesized proteins were proposed: non-selective bulk flow and cargo capture [200,201]. In principle, they are not mutually exclusive but rather cooperate to different extents, depending on the type of protein [202]. For bulk-flow the basic protein machinery for ongoing vesicle traffic is sufficient and no additional factors are needed. In plant cells, it is efficient enough to maintain the rate of soluble protein transport through the secretory pathway [203]. In contrast, cargo capture is a selective process and requires both the presence of sorting signals on proteins and specialized protein machinery to carry out segregation and cargo concentration on the donor compartment. In this case, cargo is concentrated before exiting the donor compartment.

Protein loading and vesicle transport among different membrane compartments rely on action of small monomeric GTPases. The Arabidopsis genome contains 93 genes that encode small GTPases [204]. The high level of evolutionary conservation of GTPases in eukaryotes implies their significance in cellular signaling processes [205]. Among them Rab, Rho and Arf GTPase families function in distinct steps of membrane trafficking, from formation of vesicles on donor membranes, to directing trafficking specificity, and ending with facilitating of vesicle docking and fusion with the target membranes [206-208]. Arabidopsis Arf GTPase family has 21 proteins, and its members mediate 
the assembly of several sets of coat protein complexes [204]. For example, AtARF1 facilitates the assembly of COPI-coats and the AtSAR1 mediates the ER-to-Golgi transport by COPII-coated vesicles. The second family of proteins that determine organelle identity and provide specificity for targeted membrane fusion events SNARE families $[83,208,209]$. RAB GTPases promote the initial docking, whereas subsequent fusions of vesicles and target membranes is executed by SNAREs. SNAREs form a complex in which 3 glutamine-bearing proteins $(\mathrm{Qa}, \mathrm{Qb}, \mathrm{Qc})$ and one arginine $(\mathrm{R})$ component are necessary to drive a membrane fusion [210]. In vivo a functional SNARE complex is formed only by the cognate SNARE partners, though in vitro as long as a member of each subclass is present there is no discrimination between cognate and non-cognate sets [211]. Apparently, in plant cells the specificity is achieved through the presence of additional mechanisms, possibly through the action of proof-reading proteins such as SM-proteins, and/or by lateral segregation of SNAREs at the contact site of fusing organelles [212]. In Arabidopsis there are 54 SNARE genes, including 18 Qa-SNAREs (syntaxins), 11 Qb-SNAREs, 8 Qc-SNAREs, 14 R-SNAREs (VAMPs) and 3 SNAPs (Qb/Qc) [213]. Most of them are located on specific intracellular compartments: 6 in the ER, 9 in the Golgi, 4 in the TGN, 2 in endosomes, 17 on the PM, 7 in PVC/vacuoles, 2 in TGN/PVC/vacuoles, and 1 in TGN/PVC/PM.

Post-Golgi transport is directed to the PM for secretion or to the tonoplast for vacuole deposition. Along with secretory routes there is endocytic traffic and both retrieval of trafficking machinery and degradation of already dispensable proteins is ongoing. Therefore, tightly regulated molecular mechanisms are required to coordinate multidirectional vesicle movement. Correct vesicle targeting relies on the presence of specific tags on the donor compartment and fitting tags on the vesicles. The first selection step is mediated by selective cargo sorting to the different types of vesicles in the donor compartment. It is achieved by interactions of specific sorting signals belonging to the cargo molecules with membrane receptors and coat proteins in the cytosol. Immunolocalization data suggests that annexins are good candidates for participating in the last secretory pathway in plant cells.

After vesicle budding and uncoating, the molecular mechanisms enabling the precise direction of trafficking vesicles to their appropriate destinations rely on differential labeling of target membranes. This is achieved by specific lipid composition, such as the previously mentioned increased content of sterols and thickness along the secretory pathway, and enrichment in specific molecular species of minor lipid components synthesized in situ, such as phosphatidylinositol (PtdIns). ANXA2 was shown to be important in the formation of membrane domains at the site of exocytosis in animal cells as well as was also found on clathrin-coated vesicles [214] and contains two motifs for interacting with clathrin recruiting proteins [215]. These observations led to the suggestion that ANXA2 could be responsible for coupling of exo- and endocytosis events [216]. Based on these results, plant annexins may be expected to also modulate exo- and endocytosis via lateral organization of membrane microdomains. Endo- and exocytosis need to be balanced and negatively charged phosphoinositides (PIs, phosphorylated derivatives of phosphatidylinositol) regulate both these processes. As will be discussed later in this review, in addition to annexins there are other trafficking proteins that can bind PIs such as certain epsin and clathrin adaptor proteins.

Phosphatidylinositol and its phosphorylated forms are minor nonstructural components of biological membranes present mainly on the cytoplasmic leaflet of the PM. Their transient occurrence due to a high rate of metabolic turnover suit them well to regulate a wide variety of cellular processes, including different aspects of membrane trafficking [28,217]. In mammalian cells, PIs are implicated both in the exocytosis [218] and endocytosis [219,220]. PIs seems to exert their functions via various mechanisms. First, they are able to recruit specific cytosol proteins that recognize specific head groups protruding from the plane of membrane into the cytosol via specialized protein domains [221-223]. A number of proteins regulated by PI-binding have already been identified. During clathrin-mediated endocytosis (CME) PIs-binding proteins, such as AP-2, AP180, epsin, and dynamin coordinate the recruitment of vesicle coat proteins [224]. Second, due to inverted conical shape [225] local accumulation of PIs can affect biophysical properties of membranes facilitating development of areas of increased membrane curvature [226,227]. Consequently, PIs are able to simultaneously 
stabilize transient stages of secretory vesicles fusion with the plasma membrane during $\mathrm{Ca}^{2+}$-triggered exocytosis and vesicle budding towards the cytosol during endocytosis [228]. It was found that the level of phosphatidylinositol 4,5-bisphosphate $\left(\operatorname{Ptd} \operatorname{Ins}(4,5) \mathrm{P}_{2}\right)$ determines the rate of vesicle priming, the size of the readily releasable vesicle pool, and ongoing rates of exocytosis in stimulated cells [227] as well as regulate SNARE dependent fusion [229]. Third, PIs can act as precursors for the formation of soluble inositol polyphosphates.

There are remarkable differences in the spectrum of phosphorylated PI-based species between plants and other eukaryotes. Only five of the seven known PI species have been detected, namely the phosphatidylinositol monophosphates: PtdIns3P, PtdIns4P and PtdIns5P, and the phosphtidyloinositol bisphosphates: PtdIns $(3,5) \mathrm{P}_{2}$ and PtdIns $(4,5) \mathrm{P}_{2}$ with PtdIns4P being the most abundant [230], while PtdIns $(3,4) \mathrm{P}_{2}$ and $\operatorname{PtdIns}(3,4,5) \mathrm{P}_{3}$ have not been detected yet in plants. Detailed information on the molecular targets of PIs is still not available. The results obtained so far indicate that PtdIns are involved in the regulation of the central machinery for membrane trafficking and protein sorting. Analysis with fluorescent probes specific for particular species of $\operatorname{PtdIns~revealed~that~} \operatorname{PtdIns}(4,5) \mathrm{P}_{2}$ is predominantly present in the PM at the tip of growing root hairs upon salt stress, PtdIns3P in motile membranous structures, or tonoplast and PtdIns4P in the TGN and the PM [231-233]. This distribution patterns at least to some extent coincide with the subcellular localization of the individual kinases catalyzing PI-synthesis and the phenotypes of the respective knock-out mutants [234,235]. Overall, the general conclusion is that the delivery/retrieval of vesicles to and from the PM is accompanied with a progressively increasing degree of phosphorylation (PtdIns $\left.\rightarrow \operatorname{PtdIns} 4 \mathrm{P} \rightarrow \operatorname{PtdIns}(4,5) \mathrm{P}_{2}\right)$ in subsequent membranes [234]. It appears that PIs in plants are also involved in controlling the central machinery for membrane trafficking and protein sorting. Thus, they affect essential processes, such as the establishment of cell polarity or cell wall deposition during plant growth, development [234] and environmental responses [236].

Although in biological membranes the preferred phospholipid ligand of annexins is phosphtidylserine certain annexins also have affinity for other anionic phospholipids, among them particular PI. For example, ANXA2, ANXA8 and possibly ANXA1 display a calcium-enhanced affinity for phosphatidylinositol-4,5-bisphosphate, though for the latter the data are conflicting [237-240]. Despite lack of a well-defined PtdIns-binding domain in annexins, this interaction is direct and specific. Binding of ANXA2 to PtdIns $(4,5) \mathrm{P}_{2}$ induces formation or stabilization of actin assembly sites at cellular membranes [238,239]. PtdIns $(4,5) \mathrm{P}_{2}$ is localized in cholesterol-rich membrane microdomains in the PM [241], and ANXA2 was shown to cooperatively bind to cholesterol- and PtdIns $(4,5) \mathrm{P}_{2}$ containing bilayers [135], which suggests that ANXA2 can also be implicated in lateral organization of membranes [242]. The selectivity of plant annexins toward PIs has not been analyzed experimentally yet, but the similarity in the overall structure among plant and animal annexins strongly suggests that there can be similarities in their mode of action.

\subsection{Between Golgi and Plasma Membrane: Forward Route and Exocytosis}

Soluble secretory proteins without sorting signals are secreted by default $[243,244]$. Similarly, membrane proteins that enter the secretory pathway are directed to the PM unless they have some $\mathrm{tag} / \mathrm{tags}$ exporting them to the vacuoles $[66,245]$. Analysis of the transport of fluorescently labeled protein revealed that traffic between the Golgi and the PM is direct and rapid, without any specific compartments in-between [246]. The departure from the Golgi occurs by bulk flow, with no additional delay on the way to the cell periphery. Secretory vesicles of different sizes, which can carry mixed cargos of polysaccharides or polysaccharides/glycoproteins, mediate the transport of polysaccharide precursors to the cell surface [246]. Once released from the Golgi the secretory vesicles may undergo maturation, during which final cargo modifications, such as esterification of pectins or further polymerization of polysaccharides may occur [52]. However, recent experiments performed on mammalian and yeast cells $[247,248]$ suggest that this picture of the pathway is an oversimplification, and secretion is an active process regulated by $\mathrm{Ca}^{2+}$-binding proteins, secretory cargo-sequestering 
proteins, and a TGN localized $\mathrm{Ca}^{2+}$ pump. Similar mechanisms could also exist in plants [62], which for a long time were thought to lack $\mathrm{Ca}^{2+}$-regulated exocytosis, similar to yeast. Exocytosis is a general term for denoting of the final step in the secretory pathway in which secretory vesicles fuse with the PM. The donor compartments for exocytosis are mostly (but not exclusively) the TNG, but secretory vesicles can also originate from the ER, cis-Golgi and MVB/PVC. The actin cytoskeleton provides a mechanism for vesicle delivery to the PM [249]. After arrival to the membrane, vesicles tether to the membrane, and after the fusion of these two membranes mediated by a SNARE complex, the content of the vesicle lumen is released to the apoplast. Tethering locates exocytotic vesicles to specific PM domains enriched in $\operatorname{PtdIns}(4,5) \mathrm{P}_{2}$, and with a specific lipid content which favors membrane fusion, [250] and this process is mediated by a multisubunit complex called the exocyst. In plants homologues of all eight exocyst subunits identified in animals and yeasts (SEC3, SEC5, SEC6, SEC8, SEC10, SEC15, EXO70, EXO84) have been identified [250].

Because coalescence of the vesicles and PMs results in a net increase of membrane surface, exocytosis has to be counterbalanced by endocytosis to maintain a stable cell volume. For example, during guard cells opening their volume and the PM area increase up to about $50 \%$ due to coordinated vesicle fusion and fission [251-254]. Knowledge on the exocytosis mechanisms in plant cells is substantially less advanced compared to knowledge about endocytosis. Exocytosis in plants seems to be regulated, inducible process. The previously proposed distinction between "constitutive" and "regulated" exocytosis is misleading, at least in terms of the molecular mechanism, which appears to be basically the same in different secretion events. It is now thought that plant secretion is always regulated, but that fusion with the PM is not the rate-limiting step. Plant secretion is thus regulated in different time scales and is co-regulated by $\mathrm{Ca}^{2+}$, which is the major trigger for regulated exocytosis in animals [249]. Thus, $\mathrm{Ca}^{2+}$-binding proteins such as annexins can have an impact on secretion and regulate this event.

Evidence testifying that some annexin are involved in exocytosis are compelling. For example, ANXA2 is able to promote the formation of GM1/cholesterol-containing lipid microdomains corresponding to active sites of exocytosis [134]. In transmission electron microscopy (TEM), it was shown that in stimulated neuroendocrine cells ANXA2 cross-links secretory granules to the PM $[255,256]$. In permeabilized chromaffin cells exogenous ANXA2 can restore activity in response to $\mathrm{Ca}^{2+}[257,258]$.

Exocytosis appears to be driven by different secretory pathways. One of the best recognized is SNARE-mediated exocytosis. The Arabidopsis PM contains a define set of 23 SNAREs [259]. Among them there is nine Qa syntaxins (AtSYP111/AtKNOLLE-SYP112, AtSYP121-AtSYP125, AtSYP131-AtSYP132). Possibly they form combinatorial complexes with the other Qb SNAREs located also to the PM (AtVTI12, AtNPSN11-AtNPSN13). Besides, there are also PM-specific R SNAREs (AtVAMP721-AtVAMP722, AtVAMP724-AtVAMP726) [259].

Certain animal annexins have also been shown to interact with SNARE either indirectly, by influencing organization of sterol-enriched membrane subdomains or directly, by interacting with SNARE members of complexes. In neuroendocrine adrenergic chromaffin cells stimulation induces the membrane translocation of cytosolic ANXA2 to the PM, where it forms a heterotetramer with S100A10. In turn, S100A10 can interact with VAMP2. Enzymatic cleaves of VAMP2 solubilizes S100A10 from the plasma membrane and inhibits the translocation of ANXA2 to the plasma membrane [260]. ANXA7 associates with SNAP23 both in vitro and in vivo during surfactant secretion in alveolar cells and this process is calcium-dependent [261,262]. In addition, ANXA2 was shown to regulate secretion of lung surfactant in alveolar epithelial type II cells, which occurs by physical interaction with SNAP23 [263].

It is thought that within cells, cholesterol and sphingolipids are concentrated in the PM. Fluorescence polarization studies showed that nearly half of the plasma membrane is in ordered domains at $37^{\circ} \mathrm{C}$, and about $70-80 \%$ of the surface area of several cell types is resistant to solubilization by cold Triton X-100 [264]. In polarized epithelial cells the apical membranes specialized for secretion 
are almost entirely in the liquid ordered state [265]. It was shown that ANXA2 can induce formation of PI(4,5)P2-enriched domains in the plasma membrane, which possibly influence the local membrane curvature of the lipid bilayer [128].

As indicated earlier Arabidopsis annexin ANNAT4 was recently shown to interact with AtSYP121, AtSYP122, AtSYP123, AtSYP21 and AtSYP22 [190]. The functional relevance of these interactions has yet to be determined but this annexin may regulate vesicle fusion via its ability to interact with certain SNARE complexes. It is tempting to speculate that other plant annexins may interact with specific SNARE proteins and this is an important hypothesis that needs to be tested.

\subsection{Between Golgi and Plasma Membrane: Reverse Route and Endocytosis}

Just as in animal and yeast cells, endosomes in plants shuffle both biosynthetic and endocytic cargo. During 1 fundamental role for clathrin function in cell polarity, growth, patterning, and organogenesis in plants. Over the past decades it was shown that in plant cells endocytosis plays fundamental role in establishing cell polarity, growth, patterning, and organogenesis [266,267]. Endocytosis enables cells to dynamically control the composition and functional properties of PM, for example by internalization of receptors, which would control signaling at the PM [268]. The localization of auxin efflux transporters (PINs) is also partially regulated by endocytic recycling [269] and asymmetric localization of PINs determines cell polarity and promotes the directionality of intercellular auxin flow [23]. Interestingly, expression of ANNAT2 in Arabidopsis root cap columella cells is altered in pin2 mutants in response to hypergravity [270]. The authors of this study suggest that PIN2 may be responsible for normal expression and localization of ANNAT2 during gravity responses. In plant cells endocytosis also participates in the formation of the cell plate [271]. Membrane proteins and apoplastic fluids are constantly retrieved by budding, scission and formation of endocytic vesicles, which fuse with endosomes giving early endosomes (EE). In plants the TGN functions as early endosomes receiving the exocytosed cargo [46]. The TGN functions as an early endosome and receives internalized endocytotic vesicle $[48,272,273]$.

Endocytosis is a precisely regulated process and its molecular mechanisms are tightly controlled as well as separated from another transport routes. An Arabidopsis mutant that is lacking the TGN-located component and defective in the secretory pathway displays no obvious impairment in endocytotic trafficking [274]. The elements of endocytotic machinery, i.e., lipids and appropriate receptors, are recycled back to the PM with recycling endosomes, whereas other cargo proteins undergo sorting and are delivered by late endosomes to the lytic vacuole for degradation $[275,276]$.

Endosomes can be classified according to structural features into tubular or multivesicular, or by functional criteria into sorting (SE) or recycling (RE) [277,278]. In general, transport through the endosomal system relies on maturation accomplished by component replacement. This process involves removal of the remnants of the previous traffic phase and the parallel introduction of new ones, thus gaining the competence to execute the next step in trafficking. Additionally, maturation of endosomes is accompanied by acidification of the internal lumen due to the increasing amounts and activity of the membrane V-ATPase (vesicular $\mathrm{H}^{+}$-ATPase subunit a1) [279-281]. In humans, disturbances in this process appear as a major cause of numerous neurodegenerative diseases [180].

Just as in animal and yeast (Saccharomyces cerevisiae) cells, several types of endocytosis have also been described also in plants. The primary difference in endocytosis between plant and animal cells is the mechanism of vesicle formation, which impacts both vesicle size and the material that is incorporated into the vesicles. These differences include fluid phase uptake, phagocytosis of bacteria, and lipid raft-mediated endocytosis [182]. Two types of endocytosis have been documented: clathrin-mediated and membrane microdomain-associated [44,282,283]. Regardless of the type of endocytosis, vesicles are fused with an internal membranous compartment. 


\subsection{Multivesicular Body/Prevacuolar Compartment}

MVBs are formed by the fusion of Golgi-derived vesicles carrying newly synthesized vacuolar proteins as well as from early/recycling endosomal compartments. Within MVB/PVC two kinds of sorting processes occur-the recycling of vacuolar cargo receptors mediated by the retromer complex and the sorting of PM protein into internal vesicles by the ESCRT machinery [284]. Fusion of MVBs/PVCs with the vacuole leads to the release of soluble vacuolar proteins and MVB vesicles into the lumen of the vacuole $[191,274]$. Thus, MVBs/PVCs serve as intermediate compartments that enable proteins to recycle before their fusion with the vacuole.

The characteristic feature of MVB/PVC is the presence of intraluminal vesicles (ILV). In yeast and mammals, these vesicles are thought to function as late endosomes. Generation of ILVs is coordinated by the conserved ESCRT machinery (ESCRT-0, -I, -II, -III and the VPS4 complexes) [285]. Plant genomes encode orthologs of three ESCRT-I, II and III complexes but lack ESCRT-0 [286-289]. So the other proteins, e.g., FREE1 (plant-specific and PVC-localized FYVE domain protein required for endosomal sorting) [290] and TOM1 (target of MYB) contribute to the cargo recognition [41]. RAB GTPase-mediated MVB/PVC maturation occurs by component replacement. In Arabidopsis maturation of MVB/PVC is connected with gradual replacement of Rab5 by Rab7 to form a Rab7-positive MVB/PVC. As well, fusion between MVB/PVC and autophagosomes has been observed [291].

It was shown that in Arabidopsis ANNAT3 is required for the TGN-to-MVB transport. In protoplasts from plants with suppressed expression of ANNAT3 by RNAi, maturation of MVB was disturbed, which was manifested by increased co-localization of TGN and MVB markers (YFP-AtSYP61 and mRFP-AtVSR2). Moreover, RNA interference-mediated knockdown plants ( $\Delta$ annat3) had the same phenotype as the dominant-negative mutant of VPS2, which is a member of ESCRT-III complex required for the fission of the internal vesicles in MVBs. Taken together, these results suggest that ANNAT3 is necessary for the final step of releasing MVBs as a transport carrier to the vacuole [191].

\subsection{Between Plasma Membrane and Vacuoles}

Another specificity of the plant endomembrane system, contributing an additional level to the trafficking system complexity, is the presence of different types of vacuoles in the same cells. In most mature plant cells the vast majority of the cellular volume is occupied by a large central vacuole. It provides structural support for plant cells by exerting turgor pressure against cell wall, and it drives cell expansion without the necessity to produce more cytosol. Several early studies characterized a vacuolar-specific annexin, VCaB42. This annexin binds calcium in the low nanomolar range [162], co-localizes with a Rop GTPase and is suggested to function in vacuolar biogenesis during cell expansion [292]. Central vacuoles also serve as the site for an intracellular storage of water and nutrients, waste and toxins, and as sequesters of non-active precursor forms of proteins/secondary compounds essential for interactions with the environment or other organisms [42]. Vacuoles may also support other very specialized functions, for example in guard cells, where the rapid splitting and fusion of vacuoles enable fast changes in cell volume and stomatal movement [293].

In young cells, especially during seed development, there are at least two functionally distinct types of vacuoles [294,295]-PSVs and -LVs. PSVs have a neutral $\mathrm{pH}$ and are responsible for storage of nutrients and proteins indispensable for germination and early seedlings growth, whereas the LVs are acidic and dedicated to protein degradation $[49,296,297]$. PSV and LV are believed to be separate organelles [294,298-300]. During seed germination, cell type-specific transformation of PSV into the LV can occur and PSVs are rapidly replaced by a central LV to enable rapid elongation of embryo cells [301]. In vegetative cells, e.g., in a growing root tip, the fusion of the PSV and the LV appear to occur [294]. Transport of proteins to vacuoles originates predominantly from the TGN but can also begin directly from the ER. Such a shortcut possibly represents a rapid mechanism necessary for continuous adaptation to a changing environment and adaptation to stress [302]. The LV and PSV are the final stations of the vesicular traffic. For their proper shaping an undisturbed post-Golgi trafficking is required. 
Overall, scientists are only beginning to understand the details of how the plant TGN recognizes and segregates the proteins to different vacuoles [62,303]. During cellular trafficking, proteins are targeted to defined compartments based on the presence of special integral motifs recognized by compatible receptors. Vacuolar sorting signals (VSSs) that operate in plants can be divided into three main groups. First is sequence-specific vacuolar sorting signal (ssVSR) found frequently in the LV directed protein; i.e., the N-terminal NPIR (Asn-Pro-Ile-Arg) consensus sequence that is very strict and does not tolerate variations. This sequence is usually a part of longer propeptides cleaved off during protein maturation in the PVC or in the vacuoles.

For a PSV targeted protein a non-sequence-specific cleavable C-terminal propeptide (CTPP) has been described. It is a C-terminal sequence with no clear consensus of sequence or length, but usually enriched in hydrophobic amino acids. Finally, there are signals dependent on the tertiary structure of the molecule, mostly common in storage proteins. These tertiary structures may be distributed throughout the molecule and achieve functionality only when the protein acquires its native conformation [297,304]. The VSSs are recognized by sorting receptors responsible for directing proteins to the vacuoles. So far, two types of such receptors have been described, vacuolar sorting receptors (VSRs) $[305,306]$ and receptor homology-transmembrane-RING H2 domain proteins (RMRs) [307,308].

The main route for trafficking of soluble cargo from the Golgi to the LV requires recognition of ssVSS by VSRs at the TGN, and transport to the PVC/MVB [306] by clathrin-coated vesicles before reaching the vacuoles [302]. When vesicles fuse with PVC/MVB the VSRs are recycled back to the TGN for the next round of delivery. When PVC/MVB fuse with the tonoplast, cargo molecules are released to the vacuole [65]. Such step-by-step traffic supported by the sequential action of Rab GTPases, with Rab11 mediating early transport events and the arrival of cargo at the PVC, while Rab7 mediates the final delivery to the vacuole and increases cargo levels in PVCs [207].

In contrast to soluble proteins, the sorting signals for tonoplast spanning proteins are largely unknown. At least three different pathways exist, and membrane proteins can reach the vacuoles even when Golgi and post-Golgi trafficking is blocked [63,66,309,310], possibly with the aid of autophagy machinery [311,312]. In plants, proteins with the single TMD located in the PVC contain the Yxxक motif at their C-terminal cytosolic domain [313]. However, the sorting motifs for multi-TMD proteins remain entirely unknown.

The transport of VSS-VSR complexes from the TGN is presently thought to be a passive process that relies on release of TGN from the Golgi stack and its subsequent maturation into a MVB/PVC, in a way similar to that of endosomes. Hence, only one type of $\mathrm{CCV}$ is produced that recycles membrane proteins back to the PM [60-62,314].

In Arabidopsis 9 SNAREs locate to the tonoplast, namely AtSYP21 and AtSYP22 (Qa), AtVTI11 and AtVTI13 (Qb), AtSYP51 and AtSYP52 (Qc), and AtVAMP711, AtVAMP712 and AtVAMP713(R). ANNAT4 interacts with two of these SNARES, AtSYP21 and AtSYP22, and thus is a candidate for regulating vesicle fusion with vacuolar membranes. Only one complete SNARE complex has been identified and confirmed to be involved in vacuolar trafficking, and it is an endosomal type, namely (Qa/Qb/Qc/R) AtSYP22/AtVTI11/AtSYP51/AtVAMP727 [315]. Members of SYP5-subgroup (AtSYP51 and AtSYP52) interact specifically with a syntaxins of SYP2-subgroups, as well as with the AtVTI11 to form a SNARE complex involved in the TGN-to-PVC trafficking [316].

\subsection{Leaderless Secretion}

Secretion of proteins lacking the $\mathrm{N}$-terminal signaling sequence that do not enter the classical ER-mediated secretion pathway in animals is well accepted. Four general mechanisms have been proposed: (i) direct translocation across the PM (e.g., fibroblast growth factor 1, interleukin 1 $\alpha$ ); (ii) endolysosomal pathways in which cytosol proteins are transported into intracellular vesicles called endolysosomes via protein-conducting channels (IL-1 $\beta$ and HMBG1); the fusion of endolysosomes with the cell membrane and release of the proteins into the apoplast; (iii) exosome-mediated secretion; and (iv) membrane blebbing or microvesicle shedding [317]. 
Annexins do not contain $\mathrm{N}$-terminal signaling sequences in their primary amino acid sequence directing them to be secreted, however they have been detected in phloem sap and in the extracellular matrix in plants [318-321]. Extracellular vesicles/exosomes have been identified in plants and like animal exosomes have been suggested to function in part as a novel way for proteins without signal peptides to be secreted [322]. Interestingly, the presence of ANNAT1 and other membrane trafficking proteins including AtSYP121 and AtSYP122 was recently documented in Arabidopsis exosomes [323].

Recently, non-classical secretion was shown to be rapidly modified in response to biotic stress. Upon induction with salicylic acid, the secretion of a large number of usually cytosolic enzymes that lack a classical signal peptide, such as superoxide dismutases, occurs soon after the salicylic treatment occurs $[321,324,325]$.

\section{Future Perspectives-Potential Mechanisms of Annexins' Effect on Cellular Trafficking}

Although there is strong evidence for the involvement of annexins in plant membrane trafficking, thus far there is not much known about the details of annexin function in specific membrane trafficking events, with the notable exception of evidence that ANNAT3 functions in post-TGN vesicular transport of soluble vacuolar proteins [191]. In general, it appears that plant annexins play important roles in the ESP as well as in the LSP, including post-Golgi trafficking (Figure 3). Because annexins bind membranes in response to an increase in cytosolic $\mathrm{Ca}^{2+}$ levels, they may act similarly to the $\mathrm{Ca}^{2+}$ sensor, calmodulin, with the main difference that they transduce the $\mathrm{Ca}^{2+}$ signal into membrane structures and in this way may act as a $\mathrm{Ca}^{2+}$-dependent activators for secretion.

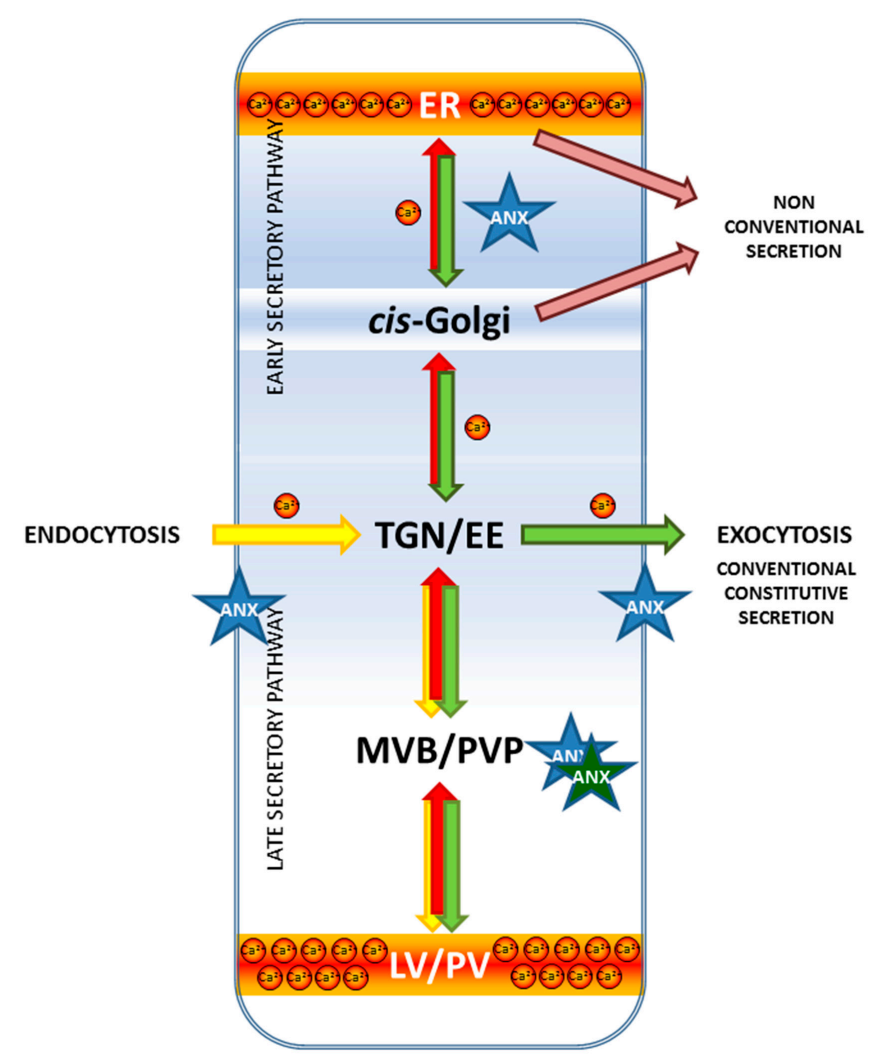

Figure 3. Potential targets for annexin participation in intracellular transport in plant cells. There is evidence that annexins participate in both the early and late secretory pathways including endoand exocytosis. Annexins are also suggested to function in conventional constitutive secretion as well as non-conventional secretion; green arrow-forward route, red arrow-reverse route; yellow arrow-endocytic route. 
It is also possible that certain plant annexins could modulate specific endomembrane vesicle fusion events by modifying the $\mathrm{pH}$ and membrane potential of endomembrane vesicles. Future research should test the specific membrane and protein interactions of individual annexins in order to gain a better understanding of the contribution of annexins to plant membrane trafficking.

Acknowledgments: We thank Grażyna Dobrowolska, Olga Sztatelman and Stanley Roux, for critical reading of the manuscript. This work was supported by the National Science Centre, Poland (grant 2012/06/M/NZ3/00156 to Dorota Konopka-Postupolska), and the National Science Foundation, US (grant IOS-1027514 to Stanley J. Roux and Greg Clark) and the National Aeronautics and Space Administration, US (grant NNX13AM54G to Stanley J. Roux and Greg Clark).

Author Contributions: Dorota Konopka-Postupolska and Greg Clark participate in preparation of manuscript; Greg Clark edited the text.

Conflicts of Interest: The authors declare no conflict of interest.

\section{References}

1. Konopka-Postupolska, D.; Clark, G.; Hofmann, A. Structure, function and membrane interactions of plant annexins: An update. Plant Sci. 2011, 181, 230-241. [CrossRef] [PubMed]

2. Cantacessi, C.; Seddon, J.M.; Miller, T.L.; Leow, C.Y.; Thomas, L.; Mason, L.; Willis, C.; Walker, G.; Loukas, A.; Gasser, R.B.; et al. A genome-wide analysis of annexins from parasitic organisms and their vectors. Sci. Rep. 2013, 3. [CrossRef] [PubMed]

3. Clark, G.B.; Morgan, R.O.; Fernandez, M.-P.; Roux, S.J. Evolutionary adaptation of plant annexins has diversified their molecular structures, interactions and functional roles. New Phytol. 2012, 196, 695-712. [CrossRef] [PubMed]

4. Morgan, R.O.; Martin-Almedina, S.; Iglesias, J.M.; Gonzalez-Florez, M.I.; Fernandez, M.P. Evolutionary perspective on annexin calcium-binding domains. Biochim. Biophys. Acta 2004, 1742, 133-140. [CrossRef] [PubMed]

5. Morgan, R.O.; Martin-Almedina, S.; Garcia, M.; Jhoncon-Kooyip, J.; Fernandez, M.-P. Deciphering function and mechanism of calcium-binding proteins from their evolutionary imprints. Biochim. Biophys. Acta 2006, 1763, 1238-1249. [CrossRef] [PubMed]

6. Konopka-Postupolska, D.; Clark, G.; Goch, G.; Debski, J.; Floras, K.; Cantero, A.; Fijolek, B.; Roux, S.; Hennig, J. The role of annexin 1 in drought stress in Arabidopsis. Plant Physiol. 2009, 150, 1394-1410. [CrossRef] [PubMed]

7. Laohavisit, A.; Davies, J.M. Multifunctional annexins. Plant Sci. 2009, 177, 532-539. [CrossRef]

8. Laohavisit, A.; Davies, J.M. Annexins. New Phytol. 2011, 189, 40-53. [CrossRef] [PubMed]

9. Laohavisit, A.; Brown, A.T.; Cicuta, P.; Davies, J.M. Annexins: Components of the calcium and reactive oxygen signaling network. Plant Physiol. 2010, 152, 1824-1829. [CrossRef] [PubMed]

10. Szalonek, M.; Sierpien, B.; Rymaszewski, W.; Gieczewska, K.; Garstka, M.; Lichocka, M.; Sass, L.; Paul, K.; Vass, I.; Vankova, R.; et al. Potato annexin STANN1 promotes drought tolerance and mitigates light stress in transgenic Solanum tuberosum L. Plants. PLoS ONE 2015, 10, e0132683. [CrossRef] [PubMed]

11. Chu, P.; Chen, H.; Zhou, Y.; Li, Y.; Ding, Y.; Jiang, L.; Tsang, E.W.T.; Wu, K.; Huang, S. Proteomic and functional analyses of Nelumbo nucifera annexins involved in seed thermotolerance and germination vigor. Planta 2012, 235, 1271-1288. [CrossRef] [PubMed]

12. Jami, S.K.; Clark, G.B.; Turlapati, S.A.; Handley, C.; Roux, S.J.; Kirti, P.B. Ectopic expression of an annexin from Brassica juncea confers tolerance to abiotic and biotic stress treatments in transgenic tobacco. Plant Physiol. Biochem. 2008, 46, 1019-1030. [CrossRef] [PubMed]

13. Lizarbe, M.; Barrasa, J.; Olmo, N.; Gavilanes, F.; Turnay, J. Annexin-phospholipid interactions. Functional implications. Int. J. Mol. Sci. 2013, 14, 2652-2683. [CrossRef] [PubMed]

14. Surpin, M.; Zheng, H.; Morita, M.T.; Saito, C.; Avila, E.; Blakeslee, J.J.; Bandyopadhyay, A.; Kovaleva, V.; Carter, D.; Murphy, A.; et al. The VTI family of SNARE proteins is necessary for plant viability and mediates different protein transport pathways. Plant Cell 2003, 15, 2885-2899. [CrossRef] [PubMed]

15. Bassil, E.; Coku, A.; Blumwald, E. Cellular ion homeostasis: Emerging roles of intracellular $\mathrm{NHX} \mathrm{Na}^{+} / \mathrm{H}^{+}$ antiporters in plant growth and development. J. Exp. Bot. 2012, 63, 5727-5740. [CrossRef] [PubMed] 
16. Pittman, J.K. Multiple transport pathways for mediating intracellular $\mathrm{pH}$ homeostasis: The vontribution of $\mathrm{H}^{+}$/ion exchangers. Front. Plant Sci. 2012, 3. [CrossRef] [PubMed]

17. Hamaji, K.; Nagira, M.; Yoshida, K.; Ohnishi, M.; Oda, Y.; Uemura, T.; Goh, T.; Sato, M.H.; Morita, M.T.; Tasaka, M.; et al. Dynamic aspects of ion accumulation by vesicle traffic under salt stress in Arabidopsis. Plant Cell Physiol. 2009, 50, 2023-2033. [CrossRef] [PubMed]

18. Zhu, J.; Gong, Z.; Zhang, C.; Song, C.-P.; Damsz, B.; Inan, G.; Koiwa, H.; Zhu, J.-K.; Hasegawa, P.M.; Bressan, R.A. OSM1/SYP61: A syntaxin protein in Arabidopsis controls abscisic acid-mediated and non-abscisic acid-mediated responses to abiotic stress. Plant Cell 2002, 14, 3009-3028. [CrossRef] [PubMed]

19. Kalde, M.; Nühse, T.S.; Findlay, K.; Peck, S.C. The syntaxin SYP132 contributes to plant resistance against bacteria and secretion of pathogenesis-related protein 1. Proc. Natl. Acad. Sci. USA 2007, 104, 11850-11855. [CrossRef] [PubMed]

20. Leborgne-Castel, N.; Bouhidel, K. Plasma membrane protein trafficking in plant-microbe interactions: A plant cell point of view. Front. Plant Sci. 2014, 5. [CrossRef] [PubMed]

21. Grefen, C.; Blatt, M.R. SNAREs-Molecular governors in signalling and development. Curr. Opin. Plant Biol. 2008, 11, 600-609. [CrossRef] [PubMed]

22. Hachez, C.; Laloux, T.; Reinhardt, H.; Cavez, D.; Degand, H.; Grefen, C.; de Rycke, R.; Inzé, D.; Blatt, M.R.; Russinova, E.; et al. Arabidopsis SNAREs SYP61 and SYP121 coordinate the trafficking of plasma membrane aquaporin PIP2;7 to modulate the cell membrane water permeability. Plant Cell 2014, 26, 3132-3147. [CrossRef] [PubMed]

23. Krecek, P.; Skupa, P.; Libus, J.; Naramoto, S.; Tejos, R.; Friml, J.; Zazímalová, E. The PIN-FORMED (PIN) protein family of auxin transporters. Genome Biol. 2009, 10, 249. [CrossRef] [PubMed]

24. Sutter, J.-U.; Sieben, C.; Hartel, A.; Eisenach, C.; Thiel, G.; Blatt, M.R. Abscisic acid triggers the endocytosis of the Arabidopsis KAT1 $\mathrm{K}^{+}$channel and its recycling to the plasma membrane. Curr. Biol. 2007, 17, 1396-1402. [CrossRef] [PubMed]

25. Nibau, C.; Tao, L.; Levasseur, K.; Wu, H.-M.; Cheung, A.Y. The Arabidopsis small GTPase AtRAC7/ROP9 is a modulator of auxin and abscisic acid signalling. J. Exp. Bot. 2013, 64, 3425-3437. [CrossRef] [PubMed]

26. Sun, J.; Chen, Q.; Qi, L.; Jiang, H.; Li, S.; Xu, Y.; Liu, F.; Zhou, W.; Pan, J.; Li, X.; et al. Jasmonate modulates endocytosis and plasma membrane accumulation of the Arabidopsis PIN2 protein. New Phytol. 2011, 191, 360-375. [CrossRef] [PubMed]

27. Ghanashyam, C.; Jain, M. Role of auxin-responsive genes in biotic stress responses. Plant Signal. Behav. 2009, 4, 846-848. [CrossRef] [PubMed]

28. Janmey, P.A.; Lindberg, U. Cytoskeletal regulation: Rich in lipids. Nat. Rev. Mol. Cell Biol. 2004, 5, 658-666. [CrossRef] [PubMed]

29. Creutz, C.E.; Kambouris, N.G.; Snyder, S.L.; Hamman, H.C.; Nelson, M.R.; Liu, W.; Rock, P. Effects of the expression of mammalian annexins in yeast secretory mutants. J. Cell Sci. 1992, 103, 1177-1192. [PubMed]

30. Novick, P.; Field, C.; Schekman, R. Identification of 23 complementation groups required for post-translational events in the yeast secretory pathway. Cell 1980, 21, 205-215. [CrossRef]

31. Draeger, A.; Wray, S.; Babiychuk, E.B. Domain architecture of the smooth-muscle plasma membrane: Regulation by annexins. Biochem. J. 2005, 387, 309-314. [CrossRef] [PubMed]

32. Monastyrskaya, K.; Babiychuk, E.B.; Hostettler, A.; Rescher, U.; Draeger, A. Annexins as intracellular calcium sensors. Cell Calcium 2007, 41, 207-219. [CrossRef] [PubMed]

33. Swairjo, M.A.; Concha, N.O.; Kaetzel, M.A.; Dedman, J.R.; Seaton, B.A. Ca ${ }^{2+}$-bridging mechanism and phospholipid head group recognition in the membrane-binding protein annexin V. Nat. Struct. Biol. 1995, 2, 968-974. [CrossRef] [PubMed]

34. Bitto, E.; Cho, W. Roles of individual domains of annexin I in its vesicle binding and vesicle aggregation: A comprehensive mutagenesis study. Biochemistry 1998, 37, 10231-10237. [CrossRef] [PubMed]

35. De la Fuente, M.; Ossa, C.G. Binding to phosphatidyl serine membranes causes a conformational change in the concave face of annexin I. Biophys. J. 1997, 72, 383-387. [CrossRef]

36. Moss, S.E.; Morgan, R.O. The annexins. Genome Biol. 2004, 5, 219. [CrossRef] [PubMed]

37. Rosengarth, A.; Gerke, V.; Luecke, H. X-ray structure of full-length annexin 1 and implications for membrane aggregation. J. Mol. Biol. 2001, 306, 489-498. [CrossRef] [PubMed]

38. Sparkes, I.A.; Frigerio, L.; Tolley, N.; Hawes, C. The plant endoplasmic reticulum: A cell-wide web. Biochem. J. 2009, 423, 145-155. [CrossRef] [PubMed] 
39. Ito, Y.; Uemura, T.; Nakano, A. Formation and maintenance of the Golgi apparatus in plant cells. In International Review of Cell and Molecular Biology; Elsevier: Amsterdam, The Netherlands, 2014; Volume 310, pp. 221-287.

40. Gendre, D.; Jonsson, K.; Boutté, Y.; Bhalerao, R.P. Journey to the cell surface-The central role of the trans-Golgi network in plants. Protoplasma 2015, 252, 385-398. [CrossRef] [PubMed]

41. Cui, Y.; Shen, J.; Gao, C.; Zhuang, X.; Wang, J.; Jiang, L. Biogenesis of plant prevacuolar multivesicular bodies. Mol. Plant 2016, 9, 774-786. [CrossRef] [PubMed]

42. Marty, F. Plant vacuoles. Plant Cell 1999, 11, 587-600. [CrossRef] [PubMed]

43. Neuhaus, J.-M.; Paris, N. Plant vacuoles: From biogenesis to function. In Plant Endocytosis; Šamaj, J., Baluška, F., Menzel, D., Eds.; Springer: Berlin/Heidelberg, Germany, 2005; Volume 1, pp. 63-82.

44. Fan, L.; Li, R.; Pan, J.; Ding, Z.; Lin, J. Endocytosis and its regulation in plants. Trends Plant Sci. 2015, 20, 388-397. [CrossRef] [PubMed]

45. Paez Valencia, J.; Goodman, K.; Otegui, M.S. Endocytosis and endosomal trafficking in plants. Annu. Rev. Plant Biol. 2016, 67, 309-335. [CrossRef] [PubMed]

46. Tse, Y.C.; Mo, B.; Hillmer, S.; Zhao, M.; Lo, S.W.; Robinson, D.G.; Jiang, L. Identification of multivesicular bodies as prevacuolar compartments in Nicotiana tabacum BY-2 cells. Plant Cell 2004, 16, 672-693. [CrossRef] [PubMed]

47. Tse, Y.C.; Lam, S.K.; Jiang, L. Organelle identification and characterization in plant cells: Using a combinational approach of confocal immunofluorescence and electron microscope. J. Plant Biol. 2009, 52, 1-9. [CrossRef]

48. Lam, S.K.; Tse, Y.C.; Miao, Y.; Li, H.-Y.; Wang, J.; Lo, S.W.; Jiang, L. Molecular characterization of plant prevacuolar and endosomal compartments. J. Integr. Plant Biol. 2007, 49, 1119-1128. [CrossRef]

49. Rojo, E.; Denecke, J. What is moving in the secretory pathway of plants? Plant Physiol. 2008, 147, 1493-1503. [CrossRef] [PubMed]

50. Donohoe, B.S.; Kang, B.-H.; Staehelin, L.A. Identification and characterization of COPIa- and COPIb-type vesicle classes associated with plant and algal Golgi. Proc. Natl. Acad. Sci. USA 2007, 104, 163-168. [CrossRef] [PubMed]

51. Ishii, M.; Suda, Y.; Kurokawa, K.; Nakano, A. COPI is essential for Golgi cisternal maturation and dynamics. J. Cell Sci. 2016, 129, 3251-3261. [CrossRef] [PubMed]

52. Kim, S.-J.; Brandizzi, F. The plant secretory pathway for the trafficking of cell wall polysaccharides and glycoproteins. Glycobiology 2016, 26, 940-949. [CrossRef] [PubMed]

53. Leucci, M.R.; Di Sansebastiano, G.-P.; Gigante, M.; Dalessandro, G.; Piro, G. Secretion marker proteins and cell-wall polysaccharides move through different secretory pathways. Planta 2007, 225, 1001-1017. [CrossRef] [PubMed]

54. Harholt, J.; Suttangkakul, A.; Vibe Scheller, H. Biosynthesis of pectin. Plant Physiol. 2010, 153, $384-395$. [CrossRef] [PubMed]

55. Oikawa, A.; Lund, C.H.; Sakuragi, Y.; Scheller, H.V. Golgi-localized enzyme complexes for plant cell wall biosynthesis. Trends Plant Sci. 2013, 18, 49-58. [CrossRef] [PubMed]

56. Parsons, H.T.; Christiansen, K.; Knierim, B.; Carroll, A.; Ito, J.; Batth, T.S.; Smith-Moritz, A.M.; Morrison, S.; McInerney, P.; Hadi, M.Z.; et al. Isolation and proteomic characterization of the Arabidopsis Golgi defines functional and novel components involved in plant cell wall biosynthesis. Plant Physiol. 2012, 159, 12-26. [CrossRef] [PubMed]

57. Spang, A. On vesicle formation and tethering in the ER-Golgi shuttle. Curr. Opin. Cell Biol. 2009, 21, 531-536. [CrossRef] [PubMed]

58. Drakakaki, G.; Dandekar, A. Protein secretion: How many secretory routes does a plant cell have? Plant Sci. 2013, 203-204, 74-78. [CrossRef] [PubMed]

59. Richter, S.; Voss, U.; Jürgens, G. Post-Golgi traffic in plants. Traffic 2009, 10, 819-828. [CrossRef] [PubMed]

60. Niemes, S.; Labs, M.; Scheuring, D.; Krueger, F.; Langhans, M.; Jesenofsky, B.; Robinson, D.G.; Pimpl, P. Sorting of plant vacuolar proteins is initiated in the ER: Vacuolar protein sorting. Plant J. 2010, 62, 601-614. [CrossRef] [PubMed]

61. Robinson, D.G.; Pimpl, P. Clathrin and post-Golgi trafficking: A very complicated issue. Trends Plant Sci. 2014, 19, 134-139. [CrossRef] [PubMed] 
62. Robinson, D.G.; Pimpl, P. Receptor-mediated transport of vacuolar proteins: A critical analysis and a new model. Protoplasma 2014, 251, 247-264. [CrossRef] [PubMed]

63. Viotti, C.; Krüger, F.; Krebs, M.; Neubert, C.; Fink, F.; Lupanga, U.; Scheuring, D.; Boutté, Y.; Frescatada-Rosa, M.; Wolfenstetter, S.; et al. The endoplasmic reticulum is the main membrane source for biogenesis of the lytic vacuole in Arabidopsis. Plant Cell 2013, 25, 3434-3449. [CrossRef] [PubMed]

64. Avila, E.L.; Zouhar, J.; Agee, A.E.; Carter, D.G.; Chary, S.N.; Raikhel, N.V. Tools to study plant organelle biogenesis. point mutation lines with disrupted vacuoles and high-speed confocal screening of green fluorescent protein-tagged organelles. Plant Physiol. 2003, 133, 1673-1676. [CrossRef] [PubMed]

65. Foresti, O.; Gershlick, D.C.; Bottanelli, F.; Hummel, E.; Hawes, C.; Denecke, J. A recycling-defective vacuolar sorting receptor reveals an intermediate compartment situated between prevacuoles and vacuoles in Tobacco. Plant Cell 2010, 22, 3992-4008. [CrossRef] [PubMed]

66. De Marchis, F.; Bellucci, M.; Pompa, A. Unconventional pathways of secretory plant proteins from the endoplasmic reticulum to the vacuole bypassing the Golgi complex. Plant Signal. Behav. 2013, 8, e25129. [CrossRef] [PubMed]

67. Rutherford, S.; Moore, I. The Arabidopsis Rab GTPase family: Another enigma variation. Curr. Opin. Plant Biol. 2002, 5, 518-528. [CrossRef]

68. Rapoport, T.A. Protein translocation across the eukaryotic endoplasmic reticulum and bacterial plasma membranes. Nature 2007, 450, 663-669. [CrossRef] [PubMed]

69. Liu, Y.; Li, J. Endoplasmic reticulum-mediated protein quality control in Arabidopsis. Front. Plant Sci. 2014. [CrossRef] [PubMed]

70. Marti, L.; Fornaciari, S.; Renna, L.; Stefano, G.; Brandizzi, F. COPII-mediated traffic in plants. Trends Plant Sci. 2010, 15, 522-528. [CrossRef] [PubMed]

71. Rojo, E.; Gillmor, C.S.; Kovaleva, V.; Somerville, C.R.; Raikhel, N.V. VACUOLELESS1 is an essential gene required for vacuole formation and morphogenesis in Arabidopsis. Dev. Cell 2001, 1, 303-310. [CrossRef]

72. Surpin, M.; Raikhel, N. Plant cell biology: Traffic jams affect plant development and signal transduction. Nat. Rev. Mol. Cell Biol. 2004, 5, 100-109. [CrossRef] [PubMed]

73. Kolb, C.; Nagel, M.-K.; Kalinowska, K.; Hagmann, J.; Ichikawa, M.; Anzenberger, F.; Alkofer, A.; Sato, M.H.; Braun, P.; Isono, E. FYVE1 is essential for vacuole biogenesis and intracellular trafficking in Arabidopsis. Plant Physiol. 2015, 167, 1361-1373. [CrossRef] [PubMed]

74. Cui, Y.; Zhao, Q.; Gao, C.; Ding, Y.; Zeng, Y.; Ueda, T.; Nakano, A.; Jiang, L. Activation of the Rab7 GTPase by the MON1-CCZ1 complex is essential for PVC-to-vacuole trafficking and plant growth in Arabidopsis. Plant Cell 2014, 26, 2080-2097. [CrossRef] [PubMed]

75. Lukowitz, W.; Mayer, U.; Jürgens, G. Cytokinesis in the Arabidopsis embryo involves the syntaxin-related KNOLLE gene product. Cell 1996, 84, 61-71. [CrossRef]

76. Park, M.; Song, K.; Reichardt, I.; Kim, H.; Mayer, U.; Stierhof, Y.-D.; Hwang, I.; Jurgens, G. Arabidopsis-adaptin subunit AP1M of adaptor protein complex 1 mediates late secretory and vacuolar traffic and is required for growth. Proc. Natl. Acad. Sci. USA 2013, 110, 10318-10323. [CrossRef] [PubMed]

77. Sanderfoot, A.A.; Pilgrim, M.; Adam, L.; Raikhel, N.V. Disruption of individual members of Arabidopsis syntaxin gene families indicates each has essential functions. Plant Cell 2001, 13, 659-666. [CrossRef] [PubMed]

78. Chapman, E.R. How does synaptotagmin trigger neurotransmitter release? Annu. Rev. Biochem. 2008, 77, 615-641. [CrossRef] [PubMed]

79. Di Giovanni, J.; Iborra, C.; Maulet, Y.; Leveque, C.; El Far, O.; Seagar, M. Calcium-dependent regulation of SNARE-mediated membrane fusion by calmodulin. J. Biol. Chem. 2010, 285, 23665-23675. [CrossRef] [PubMed]

80. Mahal, L.K.; Sequeira, S.M.; Gureasko, J.M.; Söllner, T.H. Calcium-independent stimulation of membrane fusion and SNARE pin formation by synaptotagmin I. J. Cell Biol. 2002, 158, 273-282. [CrossRef] [PubMed]

81. De Haro, L.; Quetglas, S.; Iborra, C.; Lévêque, C.; Seagar, M. Calmodulin-dependent regulation of a lipid binding domain in the v-SNARE synaptobrevin and its role in vesicular fusion. Biol. Cell 2003, 95, 459-464. [CrossRef]

82. Südhof, T.C. The synaptic vesicle. Annu. Rev. Neurosci. 2004, 27, 509-547. [CrossRef] [PubMed]

83. Südhof, T.C. Membrane fusion as a team effort. Proc. Natl. Acad. Sci. USA 2007, 104, 13541-13542. [CrossRef] [PubMed] 
84. Swulius, M.T.; Waxham, M.N. Ca ${ }^{2+} /$ Calmodulin-dependent protein kinases. Cell. Mol. Life Sci. 2008, 65, 2637-2657. [CrossRef] [PubMed]

85. Johannes, L.; Lledo, P.M.; Roa, M.; Vincent, J.D.; Henry, J.P.; Darchen, F. The GTPase Rab3a negatively controls calcium-dependent exocytosis in neuroendocrine cells. EMBO J. 1994, 13, 2029-2037. [PubMed]

86. Augustin, I.; Rosenmund, C.; Südhof, T.C.; Brose, N. Munc13-1 is essential for fusion competence of glutamatergic synaptic vesicles. Nature 1999, 400, 457-461. [CrossRef] [PubMed]

87. Beckers, C.J.; Balch, W.E. Calcium and GTP: Essential components in vesicular trafficking between the endoplasmic reticulum and Golgi apparatus. J. Cell Biol. 1989, 108, 1245-1256. [CrossRef] [PubMed]

88. Colombo, M.I.; Beron, W.; Stahl, P.D. Calmodulin regulates endosome fusion. J. Biol. Chem. 1997, 272, 7707-7712. [CrossRef] [PubMed]

89. Hay, J.C. Calcium: A fundamental regulator of intracellular membrane fusion? EMBO Rep. 2007, 8, $236-240$. [CrossRef] [PubMed]

90. Peters, C.; Mayer, A. $\mathrm{Ca}^{2+} /$ calmodulin signals the completion of docking and triggers a late step of vacuole fusion. Nature 1998, 396, 575-580. [PubMed]

91. Porat, A.; Elazar, Z. Regulation of intra-Golgi membrane transport by calcium. J. Biol. Chem. 2000, 275, 29233-29237. [CrossRef] [PubMed]

92. Pryor, P.R.; Mullock, B.M.; Bright, N.A.; Gray, S.R.; Luzio, J.P. The role of intraorganellar $\mathrm{Ca}^{2+}$ in late endosome-lysosome heterotypic fusion and in the reformation of lysosomes from hybrid organelles. J. Cell Biol. 2000, 149, 1053-1062. [CrossRef] [PubMed]

93. Rexach, M.F.; Schekman, R.W. Distinct biochemical requirements for the budding, targeting, and fusion of ER-derived transport vesicles. J. Cell Biol. 1991, 114, 219-229. [CrossRef] [PubMed]

94. Chen, J.-L.; Ahluwalia, J.P.; Stamnes, M. Selective effects of calcium chelators on anterograde and retrograde protein transport in the cell. J. Biol. Chem. 2002, 277, 35682-35687. [CrossRef] [PubMed]

95. Parkinson, K.; Baines, A.E.; Keller, T.; Gruenheit, N.; Bragg, L.; North, R.A.; Thompson, C.R.L. Calcium-dependent regulation of Rab activation and vesicle fusion by an intracellular P2X ion channel. Nat. Cell Biol. 2013, 16, 87-98. [CrossRef] [PubMed]

96. Miklavc, P.; Mair, N.; Wittekindt, O.H.; Haller, T.; Dietl, P.; Felder, E.; Timmler, M.; Frick, M. Fusion-activated $\mathrm{Ca}^{2+}$ entry via vesicular P2X4 receptors promotes fusion pore opening and exocytotic content release in pneumocytes. Proc. Natl. Acad. Sci. USA 2011, 108, 14503-14508. [CrossRef] [PubMed]

97. Fountain, S.J.; Burnstock, G. An evolutionary history of P2X receptors. Purinergic Signal. 2009, 5, $269-272$. [CrossRef] [PubMed]

98. Dark, A.; Demidchik, V.; Richards, S.L.; Shabala, S.; Davies, J.M. Release of extracellular purines from plant roots and effect on ion fluxes. Plant Signal. Behav. 2011, 6, 1855-1857. [CrossRef] [PubMed]

99. Demidchik, V.; Nichols, C.; Oliynyk, M.; Dark, A.; Glover, B.J.; Davies, J.M. Is ATP a signaling agent in plants? Plant Physiol. 2003, 133, 456-461. [CrossRef] [PubMed]

100. Demidchik, V.; Shang, Z.; Shin, R.; Thompson, E.; Rubio, L.; Laohavisit, A.; Mortimer, J.C.; Chivasa, S.; Slabas, A.R.; Glover, B.J.; et al. Plant extracellular ATP signalling by plasma membrane NADPH oxidase and $\mathrm{Ca}^{2+}$ channels. Plant J. Cell Mol. Biol. 2009, 58, 903-913. [CrossRef] [PubMed]

101. Jeter, C.R.; Tang, W.; Henaff, E.; Butterfield, T.; Roux, S.J. Evidence of a novel cell signaling role for extracellular adenosine triphosphates and diphosphates in Arabidopsis. Plant Cell 2004, 16, 2652-2664. [CrossRef] [PubMed]

102. Tanaka, K.; Choi, J.; Cao, Y.; Stacey, G. Extracellular ATP acts as a damage-associated molecular pattern (DAMP) signal in plants. Front. Plant Sci. 2014, 5. [CrossRef] [PubMed]

103. Clark, G.B.; Morgan, R.O.; Fernandez, M.-P.; Salmi, M.L.; Roux, S.J. Breakthroughs spotlighting roles for extracellular nucleotides and apyrases in stress responses and growth and development. Plant Sci. 2014, 225, 107-116. [CrossRef] [PubMed]

104. Choi, J.; Tanaka, K.; Cao, Y.; Qi, Y.; Qiu, J.; Liang, Y.; Lee, S.Y.; Stacey, G. Identification of a plant receptor for extracellular ATP. Science 2014, 343, 290-294. [CrossRef] [PubMed]

105. Rubio, L.; Laohavisit, A.; Mortimer, J.; Dark, A.; Davies, J. Salt stress signalling involves ATP release and Arabidopsis annexin 1. Comp. Biochem. Physiol. Part Mol. Physiol. 2009, 153, S192-S194. [CrossRef]

106. Yamasaki, A.; Tani, K.; Yamamoto, A.; Kitamura, N.; Komada, M. The $\mathrm{Ca}^{2+}$-binding protein ALG-2 is recruited to endoplasmic reticulum exit sites by Sec31A and stabilizes the localization of Sec31A. Mol. Biol Cell 2006, 17, 4876-4887. [CrossRef] [PubMed] 
107. Cao, X.; Ballew, N.; Barlowe, C. Initial docking of ER-derived vesicles requires Uso1p and Ypt1p but is independent of SNARE proteins. EMBO J. 1998, 17, 2156-2165. [CrossRef] [PubMed]

108. Munro, S. The golgin coiled-coil proteins of the Golgi apparatus. Cold Spring Harb. Perspect. Biol. 2011, 3, a005256. [CrossRef] [PubMed]

109. Mukherjee, I.; Barlowe, C. Overexpression of Sly41 suppresses COPII vesicle-tethering deficiencies by elevating intracellular calcium levels. Mol. Biol. Cell 2016, 27, 1635-1649. [CrossRef] [PubMed]

110. Schmitt, H.D.; Puzicha, M.; Gallwitz, D. Study of a temperature-sensitive mutant of the ras-related YPT1 gene product in yeast suggests a role in the regulation of intracellular calcium. Cell 1988, 53, 635-647. [CrossRef]

111. Tester, M.; Zorec, R. Cytoplasmic calcium stimulates exocytosis in a plant secretory cell. Biophys. J. 1992, 63, 864-867. [CrossRef]

112. Yaghmur, A.; Sartori, B.; Rappolt, M. The role of calcium in membrane condensation and spontaneous curvature variations in model lipidic systems. Phys. Chem. Chem. Phys. PCCP 2011, 13, 3115-3125. [CrossRef] [PubMed]

113. Shibata, H.; Kanadome, T.; Sugiura, H.; Yokoyama, T.; Yamamuro, M.; Moss, S.E.; Maki, M. A new role for annexin A11 in the early secretory pathway via stabilizing Sec31A protein at the endoplasmic reticulum exit sites (ERES). J. Biol. Chem. 2015, 290, 4981-4993. [CrossRef] [PubMed]

114. Cardenas, L.; Lovy-Wheeler, A.; Kunkel, J.G.; Hepler, P.K. Pollen tube growth oscillations and intracellular calcium levels are reversibly modulated by actin polymerization. Plant Physiol. 2008, 146, 1611-1621. [CrossRef] [PubMed]

115. Chen, D.-H.; Acharya, B.; Liu, W.; Zhang, W. Interaction between calcium and actin in guard cell and pollen signaling networks. Plants 2013, 2, 615-634. [CrossRef] [PubMed]

116. Snowman, B.N.; Kovar, D.R.; Shevchenko, G.; Franklin-Tong, V.E.; Staiger, C.J. Signal-mediated depolymerization of actin in pollen during the self-incompatibility response. Plant Cell 2002, 14, 2613-2626. [CrossRef] [PubMed]

117. Steinhorst, L.; Kudla, J. Calcium-A central regulator of pollen germination and tube growth. Biochim. Biophys. Acta BBA Mol. Cell Res. 2013, 1833, 1573-1581. [CrossRef] [PubMed]

118. Ahluwalia, J.P.; Topp, J.D.; Weirather, K.; Zimmerman, M.; Stamnes, M. A role for calcium in stabilizing transport vesicle coats. J. Biol. Chem. 2001, 276, 34148-34155. [CrossRef] [PubMed]

119. Bentley, M.; Nycz, D.C.; Joglekar, A.; Fertschai, I.; Malli, R.; Graier, W.F.; Hay, J.C. Vesicular calcium regulates coat retention, fusogenicity, and size of Pre-Golgi intermediates. Mol. Biol. Cell 2010, 21, 1033-1046. [CrossRef] [PubMed]

120. Samaj, J.; Baluska, F.; Voigt, B.; Schlicht, M.; Volkmann, D.; Menzel, D. Endocytosis, actin cytoskeleton, and signaling. Plant Physiol. 2004, 135, 1150-1161. [CrossRef] [PubMed]

121. Sticher, L.; Penel, C.; Greppin, H. Calcium requirement for the secretion of peroxidases by plant cell suspensions. J. Cell Sci. 1981, 48, 345-353. [PubMed]

122. Holdaway-Clarke, T.L.; Hepler, P.K. Control of pollen tube growth: Role of ion gradients and fluxes: Tansley review. New Phytol. 2003, 159, 539-563. [CrossRef]

123. Stael, S.; Wurzinger, B.; Mair, A.; Mehlmer, N.; Vothknecht, U.C.; Teige, M. Plant organellar calcium signalling: An emerging field. J. Exp. Bot. 2012, 63, 1525-1542. [CrossRef] [PubMed]

124. Caohuy, H.; Srivastava, M.; Pollard, H.B. Membrane fusion protein synexin (annexin VII) as a Ca ${ }^{2+} / \mathrm{GTP}$ sensor in exocytotic secretion. Proc. Natl. Acad. Sci. USA 1996, 93, 10797-10802. [CrossRef] [PubMed]

125. Chander, A.; Sen, N.; Spitzer, A.R. Synexin and GTP increase surfactant secretion in permeabilized alveolar type II cells. Am. J. Physiol. Lung Cell. Mol. Physiol. 2001, 280, L991-L998. [PubMed]

126. Lafont, F.; Lecat, S.; Verkade, P.; Simons, K. Annexin XIIIb associates with lipid microdomains to function in apical delivery. J. Cell Biol. 1998, 142, 1413-1427. [CrossRef] [PubMed]

127. Gruenberg, J.; Emans, N. Annexins in membrane traffic. Trends Cell Biol. 1993, 3, 224-227. [CrossRef]

128. Grieve, A.G.; Moss, S.E.; Hayes, M.J. Annexin A2 at the interface of actin and membrane dynamics: A focus on its roles in endocytosis and cell polarization. Int. J. Cell Biol. 2012, 2012, 1-11. [CrossRef] [PubMed]

129. Zobiack, N.; Rescher, U.; Ludwig, C.; Zeuschner, D.; Gerke, V. The annexin 2/S100A10 complex controls the distribution of transferrin receptor-containing recycling endosomes. Mol. Biol. Cell 2003, 14, 4896-4908. [CrossRef] [PubMed] 
130. Futter, C.E.; Felder, S.; Schlessinger, J.; Ullrich, A.; Hopkins, C.R. Annexin I is phosphorylated in the multivesicular body during the processing of the epidermal growth factor receptor. J. Cell Biol. 1993, 120, 77-83. [CrossRef] [PubMed]

131. Mayran, N.; Parton, R.G.; Gruenberg, J. Annexin II regulates multivesicular endosome biogenesis in the degradation pathway of animal cells. EMBO J. 2003, 22, 3242-3253. [CrossRef] [PubMed]

132. Gerke, V.; Carl, E.; Creutz, C.E.; Moss, S.E. Annexins: Linking $\mathrm{Ca}^{2+}$ signalling to membrane dynamics. Nat. Rev. Mol. Cell Biol. 2005, 6, 449-461. [CrossRef] [PubMed]

133. Monastyrskaya, K.; Babiychuk, E.B.; Draeger, A. The annexins: Spatial and temporal coordination of signaling events during cellular stress. Cell. Mol. Life Sci. 2009, 66, 2623-2642. [CrossRef] [PubMed]

134. Chasserot-Golaz, S.; Vitale, N.; Umbrecht-Jenck, E.; Knight, D.; Gerke, V.; Bader, M.-F. Annexin 2 promotes the formation of lipid microdomains required for calcium-regulated exocytosis of dense-core vesicles. Mol. Biol. Cell 2005, 16, 1108-1119. [CrossRef] [PubMed]

135. Drucker, P.; Pejic, M.; Galla, H.-J.; Gerke, V. Lipid segregation and membrane budding induced by the peripheral membrane binding protein Annexin A2. J. Biol. Chem. 2013, 288, 24764-24776. [CrossRef] [PubMed]

136. Roth, D.; Morgan, A.; Burgoyne, R.D. Identification of a key domain in annexin and 14-3-3 proteins that stimulate calcium-dependent exocytosis in permeabilized adrenal chromaffin cells. FEBS Lett. 1993, 320, 207-210. [CrossRef]

137. Burgoyne, R.D.; Morgan, A. Calcium sensors in regulated exocytosis. Cell Calcium 1998, 24, 367-376. [CrossRef]

138. Caohuy, H.; Pollard, H.B. Annexin 7: A non-SNARE proteolytic substrate for botulinum toxin type C in secreting chromaffin cells. Ann. N. Y. Acad. Sci. 2002, 971, 287-290. [CrossRef] [PubMed]

139. Futter, C.E.; White, I.J. Annexins and endocytosis. Traffic Cph. Den. 2007, 8, 951-958. [CrossRef] [PubMed]

140. Wang, S.; Sun, H.; Tanowitz, M.; Liang, X.-H.; Crooke, S.T. Annexin A2 facilitates endocytic trafficking of antisense oligonucleotides. Nucleic Acids Res. 2016, 44, 7314-7330. [CrossRef] [PubMed]

141. Eden, E.R.; Sanchez-Heras, E.; Tsapara, A.; Sobota, A.; Levine, T.P.; Futter, C.E. Annexin A1 tethers membrane contact sites that mediate ER to endosome cholesterol transport. Dev. Cell 2016, 37, 473-483. [CrossRef] [PubMed]

142. Klokk, T.I.; Kavaliauskiene, S.; Sandvig, K. Cross-linking of glycosphingolipids at the plasma membrane: Consequences for intracellular signaling and traffic. Cell. Mol. Life Sci. 2016, 73, 1301-1316. [CrossRef] [PubMed]

143. Tcatchoff, L.; Andersson, S.; Utskarpen, A.; Klokk, T.I.; Skånland, S.S.; Pust, S.; Gerke, V.; Sandvig, K. Annexin A1 and A2:rRoles in retrograde trafficking of shiga toxin. PLoS ONE 2012, 7, e40429. [CrossRef] [PubMed]

144. Valapala, M.; Vishwanatha, J.K. Lipid raft endocytosis and exosomal transport facilitate extracellular trafficking of annexin A2. J. Biol. Chem. 2011, 286, 30911-30925. [CrossRef] [PubMed]

145. White, I.J.; Bailey, L.M.; Aghakhani, M.R.; Moss, S.E.; Futter, C.E. EGF stimulates annexin 1-dependent inward vesiculation in a multivesicular endosome subpopulation. EMBO J. 2006, 25, 1-12. [CrossRef] [PubMed]

146. Mayorga, L.S.; Berón, W.; Sarrouf, M.N.; Colombo, M.I.; Creutz, C.; Stahl, P.D. Calcium-dependent fusion among endosomes. J. Biol. Chem. 1994, 269, 30927-30934. [PubMed]

147. Potez, S.; Luginbuhl, M.; Monastyrskaya, K.; Hostettler, A.; Draeger, A.; Babiychuk, E.B. Tailored protection against plasmalemmal injury by annexins with different $\mathrm{Ca}^{2+}$ sensitivities. J. Biol. Chem. 2011, 286, 17982-17991. [CrossRef] [PubMed]

148. McNeil, A.K.; Rescher, U.; Gerke, V.; McNeil, P.L. Requirement for annexin A1 in plasma membrane repair. J. Biol. Chem. 2006, 281, 35202-35207. [CrossRef] [PubMed]

149. Babiychuk, E.B.; Monastyrskaya, K.; Potez, S.; Draeger, A. Intracellular $\mathrm{Ca}^{2+}$ operates a switch between repair and lysis of streptolysin O-perforated cells. Cell Death Differ. 2009, 16, 1126-1134. [CrossRef] [PubMed]

150. Idone, V.; Tam, C.; Goss, J.W.; Toomre, D.; Pypaert, M.; Andrews, N.W. Repair of injured plasma membrane by rapid $\mathrm{Ca}^{2+}$-dependent endocytosis. J. Cell Biol. 2008, 180, 905-914. [CrossRef] [PubMed]

151. Babiychuk, E.B.; Monastyrskaya, K.; Potez, S.; Draeger, A. Blebbing confers resistance against cell lysis. Cell Death Differ. 2011, 18, 80-89. [CrossRef] [PubMed]

152. Blazek, A.D.; Paleo, B.J.; Weisleder, N. Plasmam membrane repair: A central process for maintaining cellular homeostasis. Physiology 2015, 30, 438-448. [CrossRef] [PubMed] 
153. Bouter, A.; Gounou, C.; Bérat, R.; Tan, S.; Gallois, B.; Granier, T.; d’Estaintot, B.L.; Pöschl, E.; Brachvogel, B.; Brisson, A.R. Annexin-A5 assembled into two-dimensional arrays promotes cell membrane repair. Nat. Commun. 2011, 2, 270. [CrossRef] [PubMed]

154. Swaggart, K.A.; Demonbreun, A.R.; Vo, A.H.; Swanson, K.E.; Kim, E.Y.; Fahrenbach, J.P.; Holley-Cuthrell, J.; Eskin, A.; Chen, Z.; Squire, K.; et al. Annexin A6 modifies muscular dystrophy by mediating sarcolemmal repair. Proc. Natl. Acad. Sci. USA 2014, 111, 6004-6009. [CrossRef] [PubMed]

155. Jami, S.K.; Clark, G.B.; Ayele, B.T.; Ashe, P.; Kirti, P.B. Genome-wide comparative analysis of annexin superfamily in plants. PLOS ONE 2012, 7, e47801. [CrossRef] [PubMed]

156. Clark, G.B.; Sessions, A.; Eastburn, D.J.; Roux, S.J. Differential expression of members of the annexin multigene family in Arabidopsis. Plant Physiol. 2001, 126, 1072-1084. [CrossRef] [PubMed]

157. Jami, S.K.; Clark, G.B.; Ayele, B.T.; Roux, S.J.; Kirti, P.B. Identification and characterization of annexin gene family in rice. Plant Cell Rep. 2012, 31, 813-825. [CrossRef] [PubMed]

158. Feng, Y.M.; Wei, X.K.; Liao, W.X.; Huang, L.H.; Zhang, H.; Liang, S.C.; Peng, H. Molecular analysis of the annexin gene family in soybean. Biol. Plant. 2013, 57, 655-662. [CrossRef]

159. Lu, Y.; Ouyang, B.; Zhang, J.; Wang, T.; Lu, C.; Han, Q.; Zhao, S.; Ye, Z.; Li, H. Genomic organization, phylogenetic comparison and expression profiles of annexin gene family in tomato (Solanum lycopersicum). Gene 2012, 499, 14-24. [CrossRef] [PubMed]

160. Clark, G.B.; Dauwalder, M.; Roux, S.J. Purification and immunolocalization of an annexin-like protein in pea seedlings. Planta 1992, 187. [CrossRef] [PubMed]

161. Clark, G.B.; Dauwalder, M.; Roux, S.J. Immunological and biochemical evidence for nuclear localization of annexin in peas. Plant Physiol. Biochem. 1998, 36, 621-627. [CrossRef]

162. Seals, D.F.; Parrish, M.L.; Randall, S.K. A 42-kilodalton annexin-like protein is associated with plant vacuoles. Plant Physiol. 1994, 106, 1403-1412. [CrossRef] [PubMed]

163. Blackbourn, H.; Barker, P.; Huskisson, N.; Battey, N. Properties and partial protein-sequence of plant annexins. Plant Physiol. 1992, 99, 864-871. [CrossRef] [PubMed]

164. Clark, G.B.; Lee, D.; Dauwalder, M.; Roux, S.J. Immunolocalization and histochemical evidence for the association of two different Arabidopsis annexins with secretion during early seedling growth and development. Planta 2005, 220, 621-631. [CrossRef] [PubMed]

165. Blackbourn, H.D.; Battey, N.H. Annexin-mediated secretory vesicle aggregation in plants. Physiol. Plant. 1993, 89, 27-32. [CrossRef]

166. Carroll, A.D.; Moyen, C.; Van Kesteren, P.; Tooke, F.; Battey, N.H.; Brownlee, C. Ca ${ }^{2+}$, annexins, and GTP modulate exocytosis from maize root cap protoplasts. Plant Cell 1998, 10, 1267-1276. [CrossRef] [PubMed]

167. Dalal, A.; Vishwakarma, A.; Singh, N.K.; Gudla, T.; Bhattacharyya, M.K.; Padmasree, K.; Viehhauser, A.; Dietz, K.-J.; Kirti, P.B. Attenuation of hydrogen peroxide-mediated oxidative stress by Brassica juncea annexin-3 counteracts thiol-specific antioxidant (TSA1) deficiency in Saccharomyces cerevisiae. FEBS Lett. 2014, 588, 584-593. [CrossRef] [PubMed]

168. Divya, K.; Jami, S.K.; Kirti, P.B. Constitutive expression of mustard annexin, AnnBj1 enhances abiotic stress tolerance and fiber quality in cotton under stress. Plant Mol. Biol. 2010, 73, 293-308. [CrossRef] [PubMed]

169. Gidrol, X.; Sabelli, P.A.; Fern, Y.S.; Kush, A.K. Annexin-like protein from Arabidopsis thaliana rescues delta oxyR mutant of Escherichia coli from $\mathrm{H}_{2} \mathrm{O}_{2}$ stress. Proc. Natl. Acad. Sci. USA 1996, 93, 11268-11273. [CrossRef] [PubMed]

170. Jänicke, R.U.; Porter, A.G.; Kush, A. A novel Arabidopsis thaliana protein protects tumor cells from tumor necrosis factor-induced apoptosis. Biochim. Biophys. Acta 1998, 1402, 70-78. [CrossRef]

171. Kush, A.; Sabapathy, K. Oxy5, a novel protein from Arabidopsis thaliana, protects mammalian cells from oxidative stress. Int. J. Biochem. Cell Biol. 2001, 33, 591-602. [CrossRef]

172. Reddy Sareddy, G. Novel antiproliferative and antioxidant role of BjAnn1, a mustard annexin protein in human glioblastoma cell lines. J. Cancer Sci. Ther. 2013, 5. [CrossRef]

173. Madureira, P.; Waisman, D. Annexin A2: The importance of being redox sSensitive. Int. J. Mol. Sci. 2013, 14, 3568-3594. [CrossRef] [PubMed]

174. Madureira, P.A.; Hill, R.; Miller, V.A.; Giacomantonio, C.; Lee, P.W.; Waisman, D.M. Annexin A2 is a novel cellular redox regulatory protein involved in tumorigenesis. Oncotarget 2011, 2, 1075-1093. [CrossRef] [PubMed]

175. Davies, J. Annexin-mediated calcium signalling in plants. Plants 2014, 3, 128-140. [CrossRef] [PubMed] 
176. Li, X.; Zhao, Y.; Xia, Q.; Zheng, L.; Liu, L.; Zhao, B.; Shi, J. Nuclear translocation of annexin 1 following oxygen-glucose deprivation-reperfusion induces apoptosis by regulating Bid expression via p53 binding. Cell Death Dis. 2016, 7, e2356. [CrossRef] [PubMed]

177. Zhao, B.; Wang, J.; Liu, L.; Li, X.; Liu, S.; Xia, Q.; Shi, J. Annexin A1 translocates to nucleus and promotes the expression of pro-inflammatory cytokines in a PKC-dependent manner after OGD/R. Sci. Rep. 2016, 6, 27028. [CrossRef] [PubMed]

178. Calvert, C.M. Tomato annexins p34 and p35 bind to F-actin and display nucleotide phosphodiesterase activity inhibited by phospholipid binding. Plant Cell 1996, 8, 333-342. [CrossRef] [PubMed]

179. Hoshino, D.; Hayashi, A.; Temmei, Y.; Kanzawa, N.; Tsuchiya, T. Biochemical and immunohistochemical characterization of Mimosa annexin. Planta 2004, 219. [CrossRef] [PubMed]

180. Hu, Y.-B.; Dammer, E.B.; Ren, R.-J.; Wang, G. The endosomal-lysosomal system: From acidification and cargo sorting to neurodegeneration. Transl. Neurodegener. 2015, 4. [CrossRef] [PubMed]

181. Konopka-Postupolska, D. Annexins: Putative linkers in dynamic membrane-cytoskeleton interactions in plant cells. Protoplasma 2007, 230, 203-215. [CrossRef] [PubMed]

182. Himschoot, E.; Beeckman, T.; Friml, J.; Vanneste, S. Calcium is an organizer of cell polarity in plants. Biochim. Biophys. Acta BBA Mol. Cell Res. 2015, 1853, 2168-2172. [CrossRef] [PubMed]

183. Mangano, S.; Juárez, S.P. D.; Estevez, J.M. ROS regulation of polar growth in plant cells. Plant Physiol. 2016, 171, 1593-1605. [CrossRef] [PubMed]

184. Gutierrez-Carbonell, E.; Takahashi, D.; Lüthje, S.; González-Reyes, J.A.; Mongrand, S.; Contreras-Moreira, B.; Abadía, A.; Uemura, M.; Abadía, J.; López-Millán, A.F. A shotgun proteomic approach reveals that fe deficiency causes marked changes in the protein profiles of plasma membrane and detergent-resistant microdomain preparations from $\beta$ vulgaris roots. J. Proteome Res. 2016, 15, 2510-2524. [CrossRef] [PubMed]

185. Lichocka, M.; Voigt, B.; Baluska, F.; Konopka-Postupolska, D. Annexin 1 interacts with specialized fluctuating membrane microdomains enriched in sterols. In Proceedings of the 8th Conference on Annexins, Maastricht, The Netherlands, 8-11 September 2015.

186. Luczak, M.; Krzeszowiec-Jeleń, W.; Konopka-Postupolska, D.; Wojtaszek, P. Collagenase as a useful tool for the analysis of plant cellular peripheries. Phytochemistry 2015, 112, 195-209. [CrossRef] [PubMed]

187. Wang, X.; Ma, X.; Wang, H.; Li, B.; Clark, G.; Guo, Y.; Roux, S.; Sun, D.; Tang, W. Proteomic study of microsomal proteins reveals a key role for Arabidopsis annexin 1 in mediating heat stress-induced increase in intracellular calcium levels. Mol. Cell. Proteom. 2015, 14, 686-694. [CrossRef] [PubMed]

188. Lee, S.; Lee, E.J.; Yang, E.J.; Lee, J.E.; Park, A.R.; Song, W.H.; Park, O.K. Proteomic identification of annexins, calcium-dependent membrane binding proteins that mediate osmotic stress and abscisic acid signal transduction in Arabidopsis. Plant Cell 2004, 16, 1378-1391. [CrossRef] [PubMed]

189. Carter, C.; Pan, S.; Zouhar, J.; Avila, E.L.; Girke, T.; Raikhel, N.V. The vegetative vacuole proteome of Arabidopsis thaliana reveals predicted and unexpected proteins. Plant Cell 2004, 16, 3285-3303. [CrossRef] [PubMed]

190. Fujiwara, M.; Uemura, T.; Ebine, K.; Nishimori, Y.; Ueda, T.; Nakano, A.; Sato, M.H.; Fukao, Y. Interactomics of Qa-SNARE in Arabidopsis thaliana. Plant Cell Physiol. 2014, 55, 781-789. [CrossRef] [PubMed]

191. Scheuring, D.; Viotti, C.; Kruger, F.; Kunzl, F.; Sturm, S.; Bubeck, J.; Hillmer, S.; Frigerio, L.; Robinson, D.G.; Pimpl, P.; et al. Multivesicular bodies mature from the trans-Golgi network/early endosome in Arabidopsis. Plant Cell Online 2011, 23, 3463-3481. [CrossRef] [PubMed]

192. Zhu, J.; Wu, X.; Yuan, S.; Qian, D.; Nan, Q.; An, L.; Xiang, Y. Annexin5 plays a vital role in Arabidopsis pollen development via $\mathrm{Ca}^{2+}$-dependent membrane trafficking. PLoS ONE 2014, 9, e102407. [CrossRef] [PubMed]

193. Zhu, J.; Yuan, S.; Wei, G.; Qian, D.; Wu, X.; Jia, H.; Gui, M.; Liu, W.; An, L.; Xiang, Y. Annexin5 Is essential for pollen development in Arabidopsis. Mol. Plant 2014, 7, 751-754. [CrossRef] [PubMed]

194. Wang, Q.; Kong, L.; Hao, H.; Wang, X.; Lin, J.; Samaj, J.; Baluska, F. Effects of brefeldin A on pollen germination and tube growth. Antagonistic effects on endocytosis and secretion. Plant Physiol. 2005, 139, 1692-1703. [CrossRef] [PubMed]

195. Zhang, H.; Qu, X.; Bao, C.; Khurana, P.; Wang, Q.; Xie, Y.; Zheng, Y.; Chen, N.; Blanchoin, L.; Staiger, C.J.; et al. Arabidopsis VILLIN5, an ctin filament bundling and severing protein, is necessary for normal pollen tube growth. Plant Cell 2010, 22, 2749-2767. [CrossRef] [PubMed]

196. Andrawis, A.; Solomon, M.; Delmer, D.P. Cotton fiber annexins: A potential role in the regulation of callose synthase. Plant J. 1993, 3, 763-772. [CrossRef] [PubMed] 
197. Tang, W.; He, Y.; Tu, L.; Wang, M.; Li, Y.; Ruan, Y.-L.; Zhang, X. Down-regulating annexin gene GhAnn2 inhibits cotton fiber elongation and decreases $\mathrm{Ca}^{2+}$ influx at the cell apex. Plant Mol. Biol. 2014, 85, 613-625. [CrossRef] [PubMed]

198. Wang, J.; Wang, H.-Y.; Zhao, P.-M.; Han, L.-B.; Jiao, G.-L.; Zheng, Y.-Y.; Huang, S.-J.; Xia, G.-X. Overexpression of a profilin (GhPFN2) promotes the progression of developmental phases in cotton fibers. Plant Cell Physiol. 2010, 51, 1276-1290. [CrossRef] [PubMed]

199. Zhang, F.; Jin, X.; Wang, L.; Li, S.; Wu, S.; Cheng, C.; Zhang, T.; Guo, W. A cotton annexin affects fiber elongation and secondary cell wall biosynthesis associated with $\mathrm{Ca}^{2+}$ influx, ROS homeostasis, and actin filament reorganization. Plant Physiol. 2016, 171, 1750-1770. [CrossRef] [PubMed]

200. Pfeffer, S.R.; Rothman, J.E. Biosynthetic protein transport and sorting by the endoplasmic reticulum and Golgi. Annu. Rev. Biochem. 1987, 56, 829-852. [CrossRef] [PubMed]

201. Phillipson, B.A.; Pimpl, P.; daSilva, L.L.; Crofts, A.J.; Taylor, J.P.; Movafeghi, A.; Robinson, D.G.; Denecke, J. Secretory bulk flow of soluble proteins is efficient and COPII dependent. Plant Cell 2001, 13, 2005-2020. [CrossRef] [PubMed]

202. Barlowe, C.; Helenius, A. Cargo capture and bulk flow in the early secretory pathway. Annu. Rev. Cell Dev. Biol. 2016, 32, 197-222. [CrossRef] [PubMed]

203. Thor, F.; Gautschi, M.; Geiger, R.; Helenius, A. Bulk flow revisited: Transport of a soluble protein in the secretory pathway. Traffic 2009, 10, 1819-1830. [CrossRef] [PubMed]

204. Vernoud, V.; Horton, A.C.; Yang, Z.; Nielsen, E. Analysis of the small GTPase gene superfamily of Arabidopsis. Plant Physiol. 2003, 131, 1191-1208. [CrossRef] [PubMed]

205. Cevher-Keskin, B. ARF1 and SAR1 GTPases in endomembrane trafficking in plants. Int. J. Mol. Sci. 2013, 14, 18181-18199. [CrossRef] [PubMed]

206. Gillingham, A.K.; Munro, S. The small G proteins of the ARF family and their regulators. Annu. Rev. Cell Dev. Biol. 2007, 23, 579-611. [CrossRef] [PubMed]

207. Nielsen, E.; Cheung, A.Y.; Ueda, T. The regulatory RAB and ARF GTPases for vesicular trafficking. Plant Physiol. 2008, 147, 1516-1526. [CrossRef] [PubMed]

208. Zerial, M.; McBride, H. Rab proteins as membrane organizers. Nat. Rev. Mol. Cell Biol. 2001, 2, $107-117$. [CrossRef] [PubMed]

209. Grosshans, B.L.; Ortiz, D.; Novick, P. Rabs and their effectors: Achieving specificity in membrane traffic. Proc. Natl. Acad. Sci. USA 2006, 103, 11821-11827. [CrossRef] [PubMed]

210. Bonifacino, J.S.; Glick, B.S. The mechanisms of vesicle budding and fusion. Cell 2004, 116, 153-166. [CrossRef]

211. Jahn, R.; Scheller, R.H. SNAREs—Engines for membrane fusion. Nat. Rev. Mol. Cell Biol. 2006, 7, $631-643$. [CrossRef] [PubMed]

212. Bethani, I.; Lang, T.; Geumann, U.; Sieber, J.J.; Jahn, R.; Rizzoli, S.O. The specificity of SNARE pairing in biological membranes is mediated by both proof-reading and spatial segregation. EMBO J. 2007, 26, 3981-3992. [CrossRef] [PubMed]

213. Sanderfoot, A.A.; Assaad, F.F.; Raikhel, N.V. The Arabidopsis genome. An abundance of soluble $\mathrm{N}$-ethylmaleimide-sensitive factor adaptor protein receptors. Plant Physiol. 2000, 124, 1558-1569. [CrossRef] [PubMed]

214. Turpin, E.; Russo-Marie, F.; Dubois, T.; de Paillerets, C.; Alfsen, A.; Bomsel, M. In adrenocortical tissue, annexins II and VI are attached to clathrin coated vesicles in a calcium-independent manner. Biochim. Biophys. Acta 1998, 1402, 115-130. [CrossRef]

215. Creutz, C.E.; Snyder, S.L. Interactions of annexins with the mu subunits of the clathrin assembly proteins. Biochemistry 2005, 44, 13795-13806. [CrossRef] [PubMed]

216. Houy, S.; Croisé, P.; Gubar, O.; Chasserot-Golaz, S.; Tryoen-Tóth, P.; Bailly, Y.; Ory, S.; Bader, M.-F.; Gasman, S. Exocytosis and endocytosis in neuroendocrine cells: Inseparable membranes! Front. Endocrinol. 2013, 4, 135. [CrossRef] [PubMed]

217. Czech, M.P. Dynamics of phosphoinositides in membrane retrieval and insertion. Annu. Rev. Physiol. 2003, 65, 791-815. [CrossRef] [PubMed]

218. Martin, T.F.J. PI(4,5)P2-binding effector proteins for vesicle exocytosis. Biochim. Biophys. Acta BBA Mol. Cell Biol. Lipids 2015, 1851, 785-793. [CrossRef] [PubMed] 
219. Posor, Y.; Eichhorn-Gruenig, M.; Puchkov, D.; Schöneberg, J.; Ullrich, A.; Lampe, A.; Müller, R.; Zarbakhsh, S.; Gulluni, F.; Hirsch, E.; et al. Spatiotemporal control of endocytosis by phosphatidylinositol-3,4-bisphosphate. Nature 2013, 499, 233-237. [CrossRef] [PubMed]

220. Posor, Y.; Eichhorn-Grünig, M.; Haucke, V. Phosphoinositides in endocytosis. Biochim. Biophys. Acta BBA Mol. Cell Biol. Lipids 2015, 1851, 794-804. [CrossRef] [PubMed]

221. Lemmon, M.A. Membrane recognition by phospholipid-binding domains. Nat. Rev. Mol. Cell Biol. 2008, 9, 99-111. [CrossRef] [PubMed]

222. Takenawa, T. Phosphoinositide-binding interface proteins involved in shaping cell membranes. Proc. Jpn. Acad. Ser. B Phys. Biol. Sci. 2010, 86, 509-523. [CrossRef] [PubMed]

223. Takenawa, T.; Itoh, T. Membrane targeting and remodeling through phosphoinositide-binding domains. IUBMB Life 2006, 58, 296-303. [CrossRef] [PubMed]

224. Ungewickell, E.J.; Hinrichsen, L. Endocytosis: Clathrin-mediated membrane budding. Curr. Opin. Cell Biol. 2007, 19, 417-425. [CrossRef] [PubMed]

225. Kooijman, E.; Testerink, C. Phosphatidic acid: An electrostatic/hydrogenbond switch? In Lipid Signaling in Plants; Munnik Teun: Berlin/Heidelberg, Germany, 2010; pp. 203-222.

226. Lundbaek, J.A.; Collingwood, S.A.; Ingólfsson, H.I.; Kapoor, R.; Andersen, O.S. Lipid bilayer regulation of membrane protein function: Gramicidin channels as molecular force probes. J. R. Soc. Interface 2010, 7, 373-395. [CrossRef] [PubMed]

227. Poccia, D.; Larijani, B. Phosphatidylinositol metabolism and membrane fusion. Biochem. J. 2009, 418, $233-246$. [CrossRef] [PubMed]

228. Chernomordik, L.V.; Zimmerberg, J. Bending membranes to the task: Structural intermediates in bilayer fusion. Curr. Opin. Struct. Biol. 1995, 5, 541-547. [CrossRef]

229. James, D.J.; Khodthong, C.; Kowalchyk, J.A.; Martin, T.F.J. Phosphatidylinositol 4,5-bisphosphate regulates SNARE-dependent membrane fusion. J. Cell Biol. 2008, 182, 355-366. [CrossRef] [PubMed]

230. Balla, T. Phosphoinositides: Tiny lipids with giant impact on cell regulation. Physiol. Rev. 2013, 93, 1019-1137. [CrossRef] [PubMed]

231. Vermeer, J.E.M.; Thole, J.M.; Goedhart, J.; Nielsen, E.; Munnik, T.; Gadella, T.W.J. Imaging phosphatidylinositol 4-phosphate dynamics in living plant cells. Plant J. Cell Mol. Biol. 2009, 57, 356-372. [CrossRef] [PubMed]

232. Vermeer, J.E.M.; van Leeuwen, W.; Tobeña-Santamaria, R.; Laxalt, A.M.; Jones, D.R.; Divecha, N.; Gadella, T.W.J.; Munnik, T. Visualization of PtdIns3P dynamics in living plant cells. Plant J. Cell Mol. Biol. 2006, 47, 687-700. [CrossRef] [PubMed]

233. Van Leeuwen, W.; Vermeer, J.E.M.; Gadella, T.W.J.; Munnik, T. Visualization of phosphatidylinositol 4,5-bisphosphate in the plasma membrane of suspension-cultured tobacco BY-2 cells and whole Arabidopsis seedlings. Plant J. Cell Mol. Biol. 2007, 52, 1014-1026. [CrossRef] [PubMed]

234. Heilmann, I. Phosphoinositide signaling in plant development. Dev. Camb. Engl. 2016, 143, $2044-2055$. [CrossRef] [PubMed]

235. Heilmann, M.; Heilmann, I. Plant phosphoinositides-Complex networks controlling growth and adaptation. Biochim. Biophys. Acta Mol. Cell Biol. Lipids 2015, 1851, 759-769. [CrossRef] [PubMed]

236. Hou, Q.; Ufer, G.; Bartels, D. Lipid signalling in plant responses to abiotic stress: Lipid signalling in plant responses to abiotic stress. Plant Cell Environ. 2016, 39, 1029-1048. [CrossRef] [PubMed]

237. Goebeler, V.; Ruhe, D.; Gerke, V.; Rescher, U. Annexin A8 displays unique phospholipid and F-actin binding properties. FEBS Lett. 2006, 580, 2430-2434. [CrossRef] [PubMed]

238. Hayes, M.J.; Merrifield, C.J.; Shao, D.; Ayala-Sanmartin, J.; Schorey, C.D.; Levine, T.P.; Proust, J.; Curran, J.; Bailly, M.; Moss, S.E. Annexin 2 binding to phosphatidylinositol 4,5-bisphosphate on endocytic vesicles is regulated by the stress response pathway. J. Biol. Chem. 2004, 279, 14157-14164. [CrossRef] [PubMed]

239. Hayes, M.J.; Shao, D.-M.; Grieve, A.; Levine, T.; Bailly, M.; Moss, S.E. Annexin A2 at the interface between F-actin and membranes enriched in phosphatidylinositol 4,5-bisphosphate. Biochim. Biophys. Acta 2009, 1793, 1086-1095. [CrossRef] [PubMed]

240. Rescher, U. Annexin 2 is a phosphatidylinositol (4,5)-bisphosphate binding protein recruited to actin assembly sites at cellular membranes. J. Cell Sci. 2004, 117, 3473-3480. [CrossRef] [PubMed]

241. Johnson, C.M.; Chichili, G.R.; Rodgers, W. Compartmentalization of phosphatidylinositol 4,5-bisphosphate signaling evidenced using targeted phosphatases. J. Biol. Chem. 2008, 283, 29920-29928. [CrossRef] [PubMed] 
242. Gokhale, N.A.; Abraham, A.; Digman, M.A.; Gratton, E.; Cho, W. Phosphoinositide specificity of and mechanism of lipid domain formation by Annexin A2-p11 heterotetramer. J. Biol. Chem. 2005, 280, 42831-42840. [CrossRef] [PubMed]

243. Chrispeels, M.J. Sorting of proteins in the secretory system. Annu. Rev. Plant Physiol. Plant Mol. Biol. 1991, 42, 21-53. [CrossRef]

244. Neuhaus, J.M.; Rogers, J.C. Sorting of proteins to vacuoles in plant cells. Plant Mol. Biol. 1998, 38, $127-144$. [CrossRef] [PubMed]

245. Pedrazzini, E.; Komarova, N.Y.; Rentsch, D.; Vitale, A. Traffic routes and signals for the tonoplast: Protein sorting to the tonoplast. Traffic 2013, 14, 622-628. [CrossRef] [PubMed]

246. Hawes, C.; Satiat-Jeunemaitre, B. The plant Golgi apparatus-Going with the flow. Biochim. Biophys. Acta 2005, 1744, 466-480. [CrossRef] [PubMed]

247. Von Blume, J.; Alleaume, A.-M.; Kienzle, C.; Carreras-Sureda, A.; Valverde, M.; Malhotra, V. Cab45 is required for $\mathrm{Ca}^{2+}$-dependent secretory cargo sorting at the trans-Golgi network. J. Cell Biol. 2012, 199, 1057-1066. [CrossRef] [PubMed]

248. Curwin, A.J.; von Blume, J.; Malhotra, V. Cofilin-mediated sorting and export of specific cargo from the Golgi apparatus in yeast. Mol. Biol. Cell 2012, 23, 2327-2338. [CrossRef] [PubMed]

249. Zárský, V.; Cvrcková, F.; Potocký, M.; Hála, M. Exocytosis and cell polarity in plants-exocyst and recycling domains. New Phytol. 2009, 183, 255-272. [CrossRef] [PubMed]

250. Hala, M.; Cole, R.; Synek, L.; Drdova, E.; Pecenkova, T.; Nordheim, A.; Lamkemeyer, T.; Madlung, J.; Hochholdinger, F.; Fowler, J.E.; et al. An exocyst complex functions in plant cell growth in Arabidopsis and tobacco. Plant Cell Online 2008, 20, 1330-1345. [CrossRef] [PubMed]

251. Li, B.; Liu, G.; Deng, Y.; Xie, M.; Feng, Z.; Sun, M.; Zhao, Y.; Liang, L.; Ding, N.; Jia, W. Excretion and folding of plasmalemma function to accommodate alterations in guard cell volume during stomatal closure in Vicia faba L. J. Exp. Bot. 2010, 61, 3749-3758. [CrossRef] [PubMed]

252. Li, B.; Xie, M.; Sun, M.; Jia, W. How does plasmalemma surface area accommodate alterations in guard cell volume during stomatal closing? Plant Signal. Behav. 2010, 5, 1468-1469. [CrossRef] [PubMed]

253. Shope, J.C.; Mott, K.A. Membrane trafficking and osmotically induced volume changes in guard cells. J. Exp. Bot. 2006, 57, 4123-4131. [CrossRef] [PubMed]

254. Shope, J.C.; DeWald, D.B.; Mott, K.A. Changes in surface area of intact guard cells are correlated with membrane internalization. Plant Physiol. 2003, 133, 1314-1321. [CrossRef] [PubMed]

255. Nakata, T.; Sobue, K.; Hirokawa, N. Conformational change and localization of calpactin I complex involved in exocytosis as revealed by quick-freeze, deep-etch electron microscopy and immunocytochemistry. J. Cell Biol. 1990, 110, 13-25. [CrossRef] [PubMed]

256. Senda, T.; Okabe, T.; Matsuda, M.; Fujita, H. Quick-freeze, deep-etch visualization of exocytosis in anterior pituitary secretory cells: Localization and possible roles of actin and annexin II. Cell Tissue Res. 1994, 277, 51-60. [CrossRef] [PubMed]

257. Ali, S.M.; Geisow, M.J.; Burgoyne, R.D. A role for calpactin in calcium-dependent exocytosis in adrenal chromaffin cells. Nature 1989, 340, 313-315. [CrossRef] [PubMed]

258. Sarafian, T.; Pradel, L.A.; Henry, J.P.; Aunis, D.; Bader, M.F. The participation of annexin II (calpactin I) in calcium-evoked exocytosis requires protein kinase C. J. Cell Biol. 1991, 114, 1135-1147. [CrossRef] [PubMed]

259. Uemura, T.; Ueda, T.; Ohniwa, R.L.; Nakano, A.; Takeyasu, K.; Sato, M.H. Systematic analysis of SNARE molecules in Arabidopsis: Dissection of the post-Golgi network in plant cells. Cell Struct. Funct. 2004, 29, 49-65. [CrossRef] [PubMed]

260. Umbrecht-Jenck, E.; Demais, V.; Calco, V.; Bailly, Y.; Bader, M.-F.; Chasserot-Golaz, S. S100A10-mediated translocation of annexin-A2 to SNARE proteins in adrenergic chromaffin cells undergoing exocytosis. Traffic Cph. Den. 2010, 11, 958-971. [CrossRef] [PubMed]

261. Chander, A.; Gerelsaikhan, T.; Vasa, P.K.; Holbrook, K. Annexin A7 trafficking to alveolar type II cell surface: Possible roles for protein insertion into membranes and lamellar body secretion. Biochim. Biophys. Acta BBA Mol. Cell Res. 2013, 1833, 1244-1255. [CrossRef] [PubMed]

262. Chander, A.; Gerelsaikhan, T.; Vasa, P.K. Annexin A7 interactions with SNARE protein SNAP23 are regulated by calcium and protein phosphorylation during surfactant secretion in alveolar type II cells. FASEB J. 2012, 26, S698. 
263. Wang, P.; Chintagari, N.R.; Gou, D.; Su, L.; Liu, L. Physical and functional interactions of SNAP-23 with annexin A2. Am. J. Respir. Cell Mol. Biol. 2007, 37, 467-476. [CrossRef] [PubMed]

264. Maxfield, F.R. Plasma membrane microdomains. Curr. Opin. Cell Biol. 2002, 14, 483-487. [CrossRef]

265. Simons, K.; Ikonen, E. Functional rafts in cell membranes. Nature 1997, 387, 569-572. [CrossRef] [PubMed]

266. Kitakura, S.; Vanneste, S.; Robert, S.; Löfke, C.; Teichmann, T.; Tanaka, H.; Friml, J. Clathrin mediates endocytosis and polar distribution of PIN auxin transporters in Arabidopsis. Plant Cell 2011, 23, 1920-1931. [CrossRef] [PubMed]

267. Li, R.; Rodriguez-Furlan, C.; Wang, J.; van de Ven, W.; Gao, T.; Raikhel, N.V.; Hicks, G.R. Different endomembrane trafficking pathways establish apical and basal polarities. Plant Cell 2017, 29, 90-108. [CrossRef] [PubMed]

268. Luschnig, C.; Vert, G. The dynamics of plant plasma membrane proteins: PINs and beyond. Development 2014, 141, 2924-2938. [CrossRef] [PubMed]

269. Kleine-Vehn, J.; Friml, J. Polar targeting and endocytic recycling in auxin-dependent plant development. Annu. Rev. Cell Dev. Biol. 2008, 24, 447-473. [CrossRef] [PubMed]

270. Tan, C.; Wang, H.; Zhang, Y.; Qi, B.; Xu, G.; Zheng, H. A proteomic approach to analyzing responses of Arabidopsis thaliana root cells to different gravitational conditions using an agravitropic mutant, pin 2 and its wild type. Proteome Sci. 2011, 9, 72. [CrossRef] [PubMed]

271. Dhonukshe, P.; Baluska, F.; Schlicht, M.; Hlavacka, A.; Samaj, J.; Friml, J.; Gadella, T.W.J. Endocytosis of cell surface material mediates cell plate formation during plant cytokinesis. Dev. Cell 2006, 10, 137-150. [CrossRef] [PubMed]

272. Dettmer, J.; Hong-Hermesdorf, A.; Stierhof, Y.-D.; Schumacher, K. Vacuolar $\mathrm{H}^{+}$-ATPase activity is required for endocytic and secretory trafficking in Arabidopsis. Plant Cell 2006, 18, 715-730. [CrossRef] [PubMed]

273. Lam, S.K.; Siu, C.L.; Hillmer, S.; Jang, S.; An, G.; Robinson, D.G.; Jiang, L. Rice SCAMP1 defines clathrin-coated, trans-Golgi-located tubular-vesicular structures as an early endosome in tobacco BY-2 cells. Plant Cell 2007, 19, 296-319. [CrossRef] [PubMed]

274. Geldner, N.; Jürgens, G. Endocytosis in signalling and development. Curr. Opin. Plant Biol. 2006, 9, 589-594. [CrossRef] [PubMed]

275. Park, M.; Jürgens, G. Membrane traffic and fusion at post-Golgi compartments. Front. Plant Sci. $2012,2$. [CrossRef] [PubMed]

276. Russell, M.R.G.; Nickerson, D.P.; Odorizzi, G. Molecular mechanisms of late endosome morphology, identity and sorting. Curr. Opin. Cell Biol. 2006, 18, 422-428. [CrossRef] [PubMed]

277. Perret, E.; Lakkaraju, A.; Deborde, S.; Schreiner, R.; Rodriguez-Boulan, E. Evolving endosomes: How many varieties and why? Curr. Opin. Cell Biol. 2005, 17, 423-434. [CrossRef] [PubMed]

278. Sachse, M.; Ramm, G.; Strous, G.; Klumperman, J. Endosomes: Multipurpose designs for integrating housekeeping and specialized tasks. Histochem. Cell Biol. 2002, 117, 91-104. [CrossRef] [PubMed]

279. Cain, C.C.; Sipe, D.M.; Murphy, R.F. Regulation of endocytic $\mathrm{pH}$ by the $\mathrm{Na}^{+}, \mathrm{K}^{+}$-ATPase in living cells. Proc. Natl. Acad. Sci. USA 1989, 86, 544-548. [CrossRef] [PubMed]

280. Irani, N.G.; Russinova, E. Receptor endocytosis and signaling in plants. Curr. Opin. Plant Biol. 2009, 12, 653-659. [CrossRef] [PubMed]

281. Mindell, J.A. Lysosomal acidification mechanisms. Annu. Rev. Physiol. 2012, 74, 69-86. [CrossRef] [PubMed]

282. Muller, J.; Mettbach, U.; Menzel, D.; Samaj, J. Molecular dissection of endosomal compartments in plants. Plant Physiol. 2007, 145, 293-304. [CrossRef] [PubMed]

283. Li, R.; Liu, P.; Wan, Y.; Chen, T.; Wang, Q.; Mettbach, U.; Baluska, F.; Samaj, J.; Fang, X.; Lucas, W.J.; et al. A membrane microdomain-associated protein, Arabidopsis Flot1, is involved in a clathrin-independent endocytic pathway and is required for seedling development. Plant Cell 2012, 24, 2105-2122. [CrossRef] [PubMed]

284. Viotti, C.; Bubeck, J.; Stierhof, Y.-D.; Krebs, M.; Langhans, M.; van den Berg, W.; van Dongen, W.; Richter, S.; Geldner, N.; Takano, J.; et al. Endocytic and secretory traffic in Arabidopsis merge in the trans-Golgi network/early endosome, an independent and highly dynamic organelle. Plant Cell 2010, 22, 1344-1357. [CrossRef] [PubMed]

285. Raiborg, C.; Stenmark, H. The ESCRT machinery in endosomal sorting of ubiquitylated membrane proteins. Nature 2009, 458, 445-452. [CrossRef] [PubMed] 
286. Cai, Y.; Zhuang, X.; 3, C.; Wang, X.; Jiang, L. The Arabidopsis endosomal sorting complex required for transport III regulates internal vesicle formation of the prevacuolar compartment and is required for plant development. Plant Physiol. 2014, 165, 1328-1343. [CrossRef] [PubMed]

287. Leung, K.F.; Dacks, J.B.; Field, M.C. Evolution of the multivesicular body ESCRT machinery; retention across the eukaryotic lineage. Traffic 2008, 9, 1698-1716. [CrossRef] [PubMed]

288. Spitzer, C.; Schellmann, S.; Sabovljevic, A.; Shahriari, M.; Keshavaiah, C.; Bechtold, N.; Herzog, M.; Muller, S.; Hanisch, F.-G.; Hulskamp, M. The Arabidopsis elch mutant reveals functions of an ESCRT component in cytokinesis. Development 2006, 133, 4679-4689. [CrossRef] [PubMed]

289. Winter, V.; Hauser, M.-T. Exploring the ESCRTing machinery in eukaryotes. Trends Plant Sci. 2006, 11, 115-123. [CrossRef] [PubMed]

290. Gao, C.; Luo, M.; Zhao, Q.; Yang, R.; Cui, Y.; Zeng, Y.; Xia, J.; Jiang, L. A unique plant ESCRT component, FREE1, regulates multivesicular body protein sorting and plant growth. Curr. Biol. 2014, 24, 2556-2563. [CrossRef] [PubMed]

291. Zhuang, X.; Cui, Y.; Gao, C.; Jiang, L. Endocytic and autophagic pathways crosstalk in plants. Curr. Opin. Plant Biol. 2015, 28, 39-47. [CrossRef] [PubMed]

292. Seals, D.F.; Randall, S.K. A vacuole-associated annexin protein, VCaB42, correlates with the expansion of tobacco cells. Plant Physiol. 1997, 115, 753-761. [CrossRef] [PubMed]

293. Zhang, C.; Hicks, G.R.; Raikhel, N.V. Plant vacuole morphology and vacuolar trafficking. Front. Plant Sci. 2014, 5. [CrossRef] [PubMed]

294. Paris, N.; Stanley, C.M.; Jones, R.L.; Rogers, J.C. Plant cells contain two functionally distinct vacuolar compartments. Cell 1996, 85, 563-572. [CrossRef]

295. Rogers, J.C. Multiple vacuoles in plant cells. Plant Physiol. 2008, 146, 1024-1025. [CrossRef] [PubMed]

296. Frigerio, L.; Hinz, G.; Robinson, D.G. Multiple vacuoles in plant cells: Rule or exception? Traffic 2008, 9, 1564-1570. [CrossRef] [PubMed]

297. Zouhar, J.; Rojo, E. Plant vacuoles: Where did they come from and where are they heading? Curr. Opin. Plant Biol. 2009, 12, 677-684. [CrossRef] [PubMed]

298. Hinz, G.; Hillmer, S.; Baumer, M.; Hohl, I. Vacuolar storage proteins and the putative vacuolar sorting receptor BP-80 exit the Golgi apparatus of developing pea cotyledons in different transport vesicles. Plant Cell 1999, 11, 1509-1524. [CrossRef] [PubMed]

299. Jauh, G.-Y.; Phillips, T.E.; Rogers, J.C. Tonoplast intrinsic protein isoforms as markers for vacuolar functions. Plant Cell 1999, 11, 1867-1882. [CrossRef] [PubMed]

300. Olbrich, A.; Hillmer, S.; Hinz, G.; Oliviusson, P.; Robinson, D.G. Newly formed vacuoles in root meristems of barley and pea seedlings have characteristics of both protein storage and lytic vacuoles. Plant Physiol. 2007, 145, 1383-1394. [CrossRef] [PubMed]

301. Zhang, G.F.; Staehelin, L.A. Functional compartmentation of the Golgi apparatus of plant cells: Immunocytochemical analysis of high-pressure frozen- and freeze-substituted sycamore maple suspension culture cells. Plant Physiol. 1992, 99, 1070-1083. [CrossRef] [PubMed]

302. Xiang, L.; Etxeberria, E.; van den Ende, W. Vacuolar protein sorting mechanisms in plants. FEBS J. 2013, 280, 979-993. [CrossRef] [PubMed]

303. Jurgens, G. Membrane trafficking in plants. Annu. Rev. Cell Dev. Biol. 2004, 20, 481-504. [CrossRef] [PubMed]

304. Jolliffe, N.A.; Craddock, C.P.; Frigerio, L. Pathways for protein transport to seed storage vacuoles. Biochem. Soc. Trans. 2005, 33, 1016-1018. [CrossRef] [PubMed]

305. De Marcos Lousa, C.; Gershlick, D.C.; Denecke, J. Mechanisms and concepts paving the way towards a complete transport cycle of plant vacuolar sorting receptors. Plant Cell 2012, 24, 1714-1732. [CrossRef] [PubMed]

306. Lee, Y.; Jang, M.; Song, K.; Kang, H.; Lee, M.H.; Lee, D.W.; Zouhar, J.; Rojo, E.; Sohn, E.J.; Hwang, I. Functional identification of sorting receptors involved in trafficking of soluble lytic vacuolar proteins in vegetative cells of Arabidopsis. Plant Physiol. 2013, 161, 121-133. [CrossRef] [PubMed]

307. Park, J.H.; Oufattole, M.; Rogers, J.C. Golgi-mediated vacuolar sorting in plant cells: RMR proteins are sorting receptors for the protein aggregation/membrane internalization pathway. Plant Sci. 2007, 172, 728-745. [CrossRef]

308. Wang, H.; Rogers, J.C.; Jiang, L. Plant RMR proteins: Unique vacuolar sorting receptors that couple ligand sorting with membrane internalization: Plant RMR proteins. FEBS J. 2011, 278, 59-68. [CrossRef] [PubMed] 
309. Bottanelli, F.; Foresti, O.; Hanton, S.; Denecke, J. Vacuolar transport in tobacco leaf epidermis cells involves a single route for soluble cargo and multiple routes for membrane cargo. Plant Cell 2011, 23, 3007-3025. [CrossRef] [PubMed]

310. Wolfenstetter, S.; Wirsching, P.; Dotzauer, D.; Schneider, S.; Sauer, N. Routes to the tonoplast: The sorting of tonoplast transporters in Arabidopsis mesophyll protoplasts. Plant Cell 2012, 24, 215-232. [CrossRef] [PubMed]

311. Herman, E.; Schmidt, M. Endoplasmic reticulum to vacuole trafficking of endoplasmic reticulum bodies provides an alternate pathway for protein transfer to the vacuole. Plant Physiol. 2004, 136, 3440-3446. [CrossRef] [PubMed]

312. Michaeli, S.; Avin-Wittenberg, T.; Galili, G. Involvement of autophagy in the direct ER to vacuole protein trafficking route in plants. Front. Plant Sci. 2014, 5. [CrossRef] [PubMed]

313. Happel, N.; Höning, S.; Neuhaus, J.-M.; Paris, N.; Robinson, D.G.; Holstein, S.E.H. Arabidopsis mu A-adaptin interacts with the tyrosine motif of the vacuolar sorting receptor VSR-PS1. Plant J. Cell Mol. Biol. 2004, 37, 678-693. [CrossRef]

314. Niemes, S.; Langhans, M.; Viotti, C.; Scheuring, D.; San Wan Yan, M.; Jiang, L.; Hillmer, S.; Robinson, D.G.; Pimpl, P. Retromer recycles vacuolar sorting receptors from the trans-Golgi network. Plant J. 2010, 61, 107-121. [CrossRef] [PubMed]

315. Ebine, K.; Okatani, Y.; Uemura, T.; Goh, T.; Shoda, K.; Niihama, M.; Morita, M.T.; Spitzer, C.; Otegui, M.S.; Nakano, A.; et al. A SNARE complex unique to seed plants is required for protein storage vacuole biogenesis and seed development of Arabidopsis thaliana. Plant Cell Online 2008, 20, 3006-3021. [CrossRef] [PubMed]

316. Sanderfoot, A.A.; Kovaleva, V.; Bassham, D.C.; Raikhel, N.V. Interactions between syntaxins identify at least five SNARE complexes within the Golgi/prevacuolar system of the Arabidopsis cell. Mol. Biol. Cell 2001, 12, 3733-3743. [CrossRef] [PubMed]

317. Cheng, F.; Williamson, J.D. Is there leaderless protein secretion in plants? Plant Signal. Behav. 2010, 5, $129-131$. [CrossRef] [PubMed]

318. Barnes, A.; Bale, J.; Constantinidou, C.; Ashton, P.; Jones, A.; Pritchard, J. Determining protein identity from sieve element sap in Ricinus communis L. by quadrupole time of flight (Q-TOF) mass spectrometry. J. Exp. Bot. 2004, 55, 1473-1481. [CrossRef] [PubMed]

319. Giavalisco, P.; Kapitza, K.; Kolasa, A.; Buhtz, A.; Kehr, J. Towards the proteome of Brassica napus phloem sap. Proteomics 2006, 6, 896-909. [CrossRef] [PubMed]

320. Kwon, H.-K.; Yokoyama, R.; Nishitani, K. A proteomic approach to apoplastic proteins involved in cell wall regeneration in protoplasts of Arabidopsis suspension-cultured cells. Plant Cell Physiol. 2005, 46, 843-857. [CrossRef] [PubMed]

321. Oh, I.S.; Park, A.R.; Bae, M.S.; Kwon, S.J.; Kim, Y.S.; Lee, J.E.; Kang, N.Y.; Lee, S.; Cheong, H.; Park, O.K. Secretome analysis reveals an Arabidopsis lipase involved in defense against Alternaria brassicicola. Plant Cell 2005, 17, 2832-2847. [CrossRef] [PubMed]

322. Regente, M.; Pinedo, M.; Elizalde, M.; de la Canal, L. Apoplastic exosome-like vesicles: A new way of protein secretion in plants? Plant Signal. Behav. 2012, 7, 544-546. [CrossRef] [PubMed]

323. Rutter, B.D.; Innes, R.W. Extracellular vesicles isolated from the leaf apoplast carry stress-response proteins. Plant Physiol. 2017, 173, 728-741. [CrossRef] [PubMed]

324. Cheng, F.; Blackburn, K.; Lin, Y.; Goshe, M.B.; Williamson, J.D. Absolute protein quantification by LC/MS ${ }^{\mathrm{E}}$ for global analysis of salicylic acid-induced plant protein secretion responses. J. Proteome Res. 2009, 8, 82-93. [CrossRef] [PubMed]

325. Slabas, A.R.; Ndimba, B.; Simon, W.J.; Chivasa, S. Proteomic analysis of the Arabidopsis cell wall reveals unexpected proteins with new cellular locations. Biochem. Soc. Trans. 2004, 32, 524-528. [CrossRef] [PubMed]

(C) 2017 by the authors. Licensee MDPI, Basel, Switzerland. This article is an open access article distributed under the terms and conditions of the Creative Commons Attribution (CC BY) license (http:/ / creativecommons.org/licenses/by/4.0/). 